DOI 10.15407/mics2020.11.183

УДК 94:417«16/17»(477.53)

\title{
Оксана Коваленко,
}

кандидатка історичних наук, доцентка

Інститут керамології - відділення Інституту Народознавства НАНУ

kovksana@gmail.com

https://orcid.org/0000-0003-0980-2870

\section{РОДИННИЙ НЕКРОПОЛЬ БОРОХОВИЧІВ У МІСТЕЧКУ ЛЮТЕНЬКА ГАДЯЦЬКОГО ПОЛКУ}

У статті проаналізовано матеріали археологічних досліджень цвинтаря XVII-XVIII ст. та залишків Свято-Успенської церкви в с. Лютенька (Полтавщина).

Лютеньку було засновано як слободу у 30-х pp. XVII ст. До 1646 р. була у власності Конєцпольських. У 1648-1782 pp. Лютенька функціонувала як сотенне містечко у складі Гадяцького, Полтавського, Зіньківського полків. Найтісніше іiі історія пов'язана із родиною Бороховичів, зокрема із Михайлом Андрійовичем, який у 1672-1687 pp., із незначними перервами, був гадяцьким полковим обозним, а 1687-1704 pp. - полковником. У статті розглянуто історію родини Михайла та його другої дружини Олени Іванівни, взаємовідносини останньої та дітей Максима, Федора, Івана, Феодосії і Марії, після смерті батька.

Більшість членів родини знайшли спочинок на цвинтарі спеціально збудованої у 1687 р., як родинна усипальниця, Успенської церкви. Звели її в центрі лютенської фортеці на місці старої дерев'яної церкви першої чверті XVII ст. Нова церква була мурованою, дев'ятидільною, хрещатою, п'ятибанною. Проіснувала до 1985 р. Навколо церкви у 2009-2010 рр. досліджено ділянку грунтового цвинтаря XVII-XVIII ст., всього близько 300 поховань. Вони розміщені у широтному напрямку, із тяжінням до стін храму, часто на місці старих могил.

Упродовж кінця XVII - першої чверті XVIII ст. Бороховичі ховали членів своєї родини в підземному просторі центральної частини та обабіч церкви у склепових похованнях. Археологічно вивчено 13 склепів, унікального стану збереженості, які є у фокусі цієї розвідки. Знайдено та атрибутовано поховання самого Михайла Бороховича, його дружини Олени та, ймовірно, 
1 Коваленко, 0. (2008). Звіт про дослідження на місці Успенської церкви в с. Лютенька Гадяцького району Полтавської області у 2008 році. Полтава. Науковий архів Iнституту археологї Національної академї̈ наук України (далі - HA IA НАНУ), ф. 1, 53 арк.; Коваленко, 0., \& Луговий, Р. (2009). Звіт про дослідження на місці Успенської церкви в с. Лютенька Гадяцького району Полтавської області у 2009 році. НА IA HАHУ, ф. 1, НА ПКМ, спр. 04-353, 152 арк.; Коваленко, 0., \& Луговий, Р. (2010). Звіт про дослідження на місці Успенської церкви в с. Лютенька Гадяцького району Полтавської області у 2010 році. Полтава. HA IA HАHУ, ф. 1, НА ПКМ, спр. 04-383, 223 арк.; Пошивайло, Б., \& Коваленко, 0. (2019). Цегла із фундаменту Успенської церкви в селі Лютенька в Полтавщині. В Олесь Пошивайло (Ред.), Українська керамологія (кн. XIII, т. 1, с. 200-204); Луговий, Р., \& Коваленко, 0. (2010). Дослідження Успенської церкви XVII століття в с. Лютенька. Нові дослідження пам'яток доби козаитва в Україні, 19, 121-128;

Коваленко, 0., \& Луговий, Р. (2013). Матеріали XVII ст. 3 розкопок церкви в с. Лютенька. Нові дослідження пам'яток доби козаитва в Україні, 22, 121-128.

2 Колекція знахідок із розкопок збе-

рігається у фондах Полтавського крає-

знавчого музею імені Василя Кричевського. Одяг зі склепу Олени Борохович тимчасово передано для дослідження Ірині Погоржельській, до лабораторії охоронної археологічної служби України Інституту археології національної академії наук України.

з Лазаревский, А. (1890). Борохович Михайло, Гадяцький полковник. 1687-1704 гг. Киевская старина, 9 (XXVIII), 547-551; Модзалевский, В. Л. (1908). Малороссийский родословник (Т. 2, с.

84). Киев: Типография т-ва Г. Л. Фронцкевича и Ко; Сушинський, Б. І. (2006). Михайло Борохович. Козацькі вожді України. Історія україни в образах ї̈ вождів та полководиів XV-XIX cm. Історичне есе у 2 томах (Т. II, с. 355-356). Одеса: ЯВФ; Баранець, П. (2013). Історія козаць-

184 ко-старшинського роду Бороховичів. Краєзнавство, 3, 56-60.

синів. Подано детальний опис конструкцій склепів, поховального вбрання, розміщення, супровідних обрядових речей: ікон, хрестів тощо. Матеріали кінця XVII-XVIII ст. розширюють наші уявлення та знання про різні аспекти здійснення поховань, поховальну обрядовість козацької старшини та загалом сприяють уточненню уявлень про смерть у часи Гетьманщини.

Ключові слова: Успенська церква, Лютенька, Гадяч, Михайло Борохович, Бороховичі, цвинтар, склеп, поховання, ікона, Успіння, хрест. дагогічного університету імені В. Г. Короленка та Полтавського краєзнавчого музею імені Василя Кричевського (під керівництвом Оксани Коваленко та Романа Лугового) провела археологічні дослідження на місці (рис. 1), попередні результати яких, у тезовому вигляді, вже оприлюднювали на конференціях ${ }^{1}$. Проте, зважаючи на унікальність віднайденого матеріалу ${ }^{2}$ й той факт, що немає наукових розвідок з історії родини Бороховичів, за винятком спеціалізованих статей О. Лазаревського та П. Баранця ${ }^{3}$, особливості поховань членів цієї сім’ї та деталізація окремих аспектів життя потребують докладного розгляду.

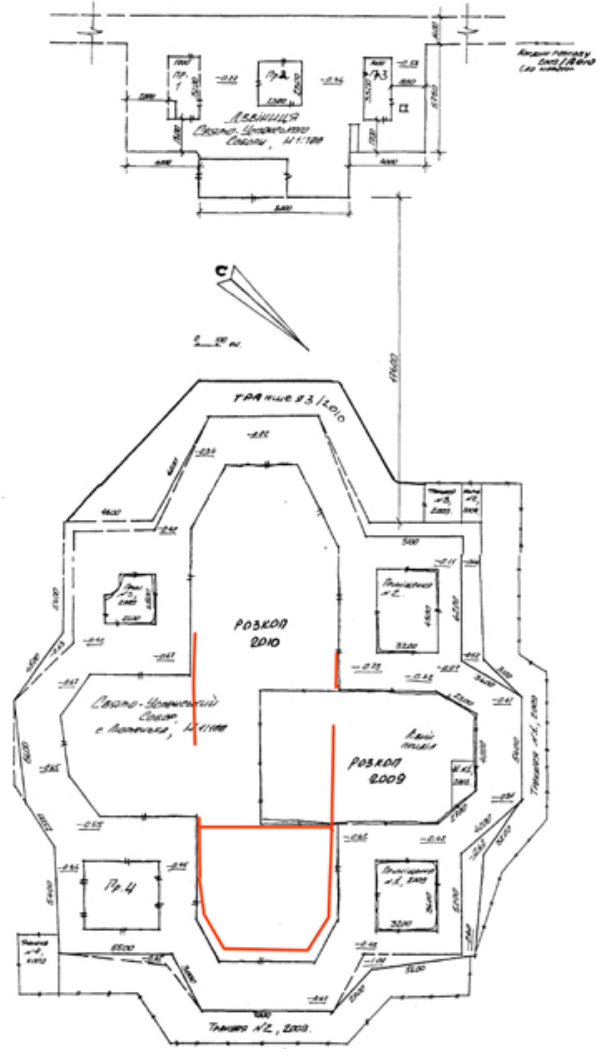

Puc. 1. Загальний план розкопу навколо фундаментів Успенської церкви в с. Лютенька 
4 Кулаковський, П. (2008). Колонізаційна діяльність Конецпольських на Київському Задніпров'ї. Записки Наукового Товариства імені Т. Г. Шевченка, CCLVI: Праці історично-філософськой секиїі, 498.

5 Кулаковський, П. Колонізаційна діяльність, 498; Грушевський, М. (1908). Господарство польського магната на Заднипровью перед Хмельниччиною. Записки українського наукового товариства в Kuєвi, 1, 25-44.

6 Коваленко, 0., \& Луговий, Р. (2010). Звіт..., арк. 6-8; Коваленко, 0., \& Луговий, Р. Матеріали XVII ст., 122125.
За даними, наведеними П. Кулаковським, Лютенька як слобода «осіла» у 1630-х рр., тоді ж осадники збудували перші укріплення ${ }^{4}$. Закріплення цієї території за Конєцпольськими відбулося за двома королівськими привілеями 1636 р.: коронний гетьман Станіслав Конєцпольський отримував у довічне володіння Переяславське староство, міста Биків, Яблунів, Березань, Миргород, Гадяч, Чумбак, Полтаву, Краснопіль, Жигмонтів, Лютенку з околицями, а також урочища Кременчук, Сoколова Гора та інші землі понад ріками Хорол, Псел, Ворскла, Оріль, Самара аж до їх упадіння у Дніпро, із правом осадження людей. Цим правом магнат скористався одразу ж, або ж привілей «де юре» підтвердив його власність на вже наявне поселення, але той факт, що Лютенька вже існувала наприкінці 1636 р., підтверджують розвідувальні дані московської сторони: царські судді під час переговорів із комісарами Речі Посполитої щодо встановлення лінії кордону у Задніпров'ї зазначали, що вздовж Псла існують «острожки» Гадяч і Сар та Лютеньки ${ }^{5}$.

Напевно, перші осадники спорудили, окрім земляних укріплень, і дерев'яну церкву, яка проіснувала до 1687 р. Писемні джерела не подають про неї відомостей, є лише згадки про побудову згодом на тому місці мурованої церкви. Однак археологічні джерела підтверджують, що дерев'яна церква була ${ }^{6}$. $\mathrm{У}$ центральній та вівтарній частинах Успен- ської церкви, 3 глибини 0,48 м від реперу, майже повторюючи контури церковних стін (на відстані 0,1-0,5 м від них), зафіксовано об'єкт, який, найімовірніше, є рештками фундаменту дерев'яної церкви, яка функціонувала до 1687 р. (рис. 2). Фундамент являв собою рівчак, завширшки 0,6 м (у центральній частині вівтаря він розширювався до 0,90 м), із вбитими, загостреними з одного кінця колодами, діаметром 18-20 cм,

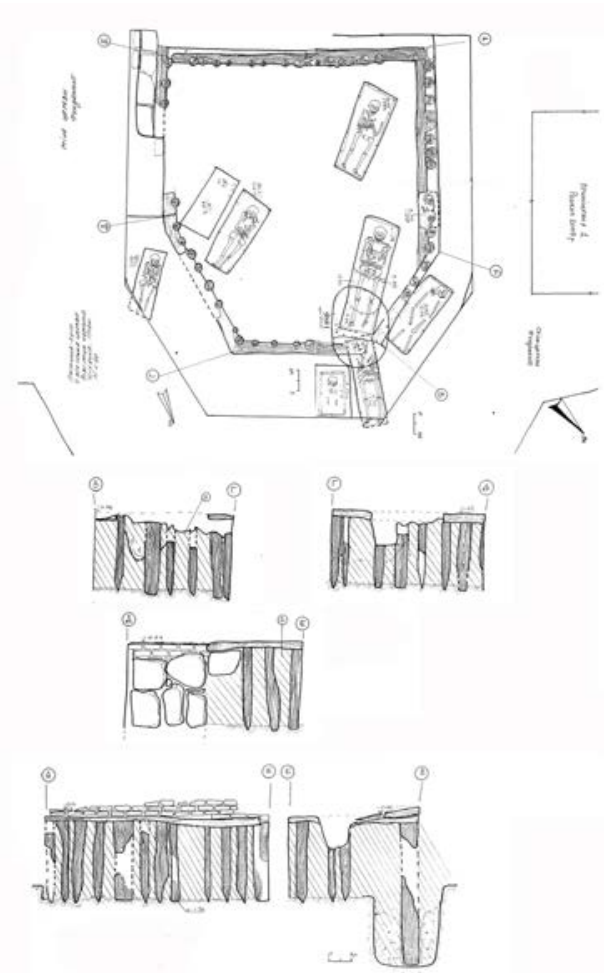

Рис. 2. Вівтарна частина храму. Поховання, план та перетини залишків дерев'яної церкви 
7 Докладніше про матеріали 3 культурного шару та опис цих поховань див.: Коваленко, 0., \& Луговий, Р. Матеріали XVII ст.,122-127.

8 Власне, чи це чітка дата завершення будівництва чи освячення, сказати наразі можна лише здогадно.

9 Кривошея, В. В. (2012). Козацька старшина Гетьманшини: енииклопедія. Київ, 112; Баранець, П. Історія, 57; Лазаревский, А. Борохович Михайло, 547.

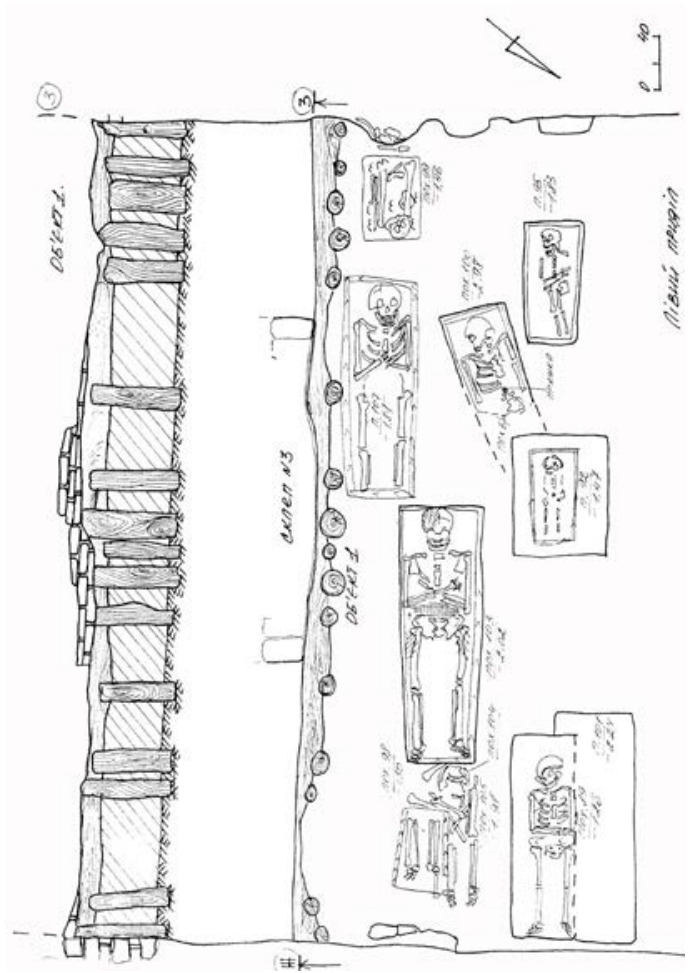

Рuc. 3. Лівий приділ храму. зверху перекритими повздовжніми балками. Дерев'яні колоди мали загострений кінець i були вставлені в рівчак. Палі вбиті на глибину 1,96 м. Широкий рівчак заглиблений до 1,70 м. Загострений кінець паль був забитий у материк, жовтий лесовий суглинок (рис. 3).

Датування цієї конструкції здійснено за знахідками у непорушному культурному шарі, який зберігся у просторі між дерев'яним і цегляним фундаментами старої та нової церков, серед яких були фрагменти глиняного гончарного посуду першої половини XVII ст. та монети - солід, викарбований у прибалтійських володіннях Швеції за королеви Крістіни (1632-1654рр.), і солід Яна II

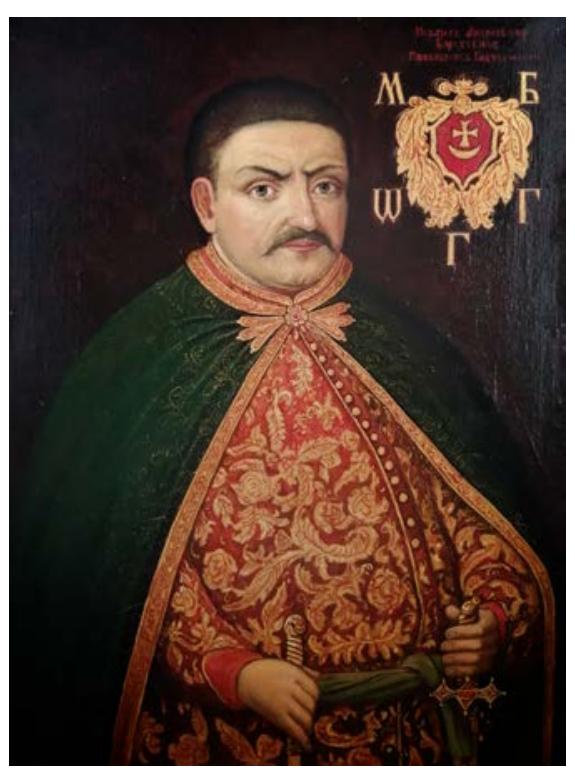

Puc. 4. Портрет гадяцького полковника Михайла Бороховича
Казимира (1649-1668 рр.). Зважаючи на те, що під час правління Крістіни шведський уряд розпочав карбування монет у Ризі із 1644 р., імовірно, об'єкт було побудовано наприкінці 1640-х - на початку 1650-х рр.

Поховання у цій частині майже не здійснювали. Через сакральність вівтарної частини, поховання в якій було чітко обумовлено, немає поховань пізнішого часу, що додатково засвідчує наявність тут дерев'яної церкви. Ховали навколо іiї стін ${ }^{7}$.

У 1686 р. на цьому місці було завершено ${ }^{8}$ будівництво Успенської мурованої церкви. Ї̈ї спорудили за ініціативи і коштом Михайла Бороховича, який на той момент був лютенським сотником (від липня 1670 р.), а від 1687 до 1704 р. - гадяцьким полковником (рис. 4) ${ }^{9}$. Коли саме Лютенька опинилася у володінні роду Бороховичів, даних поки що немає.

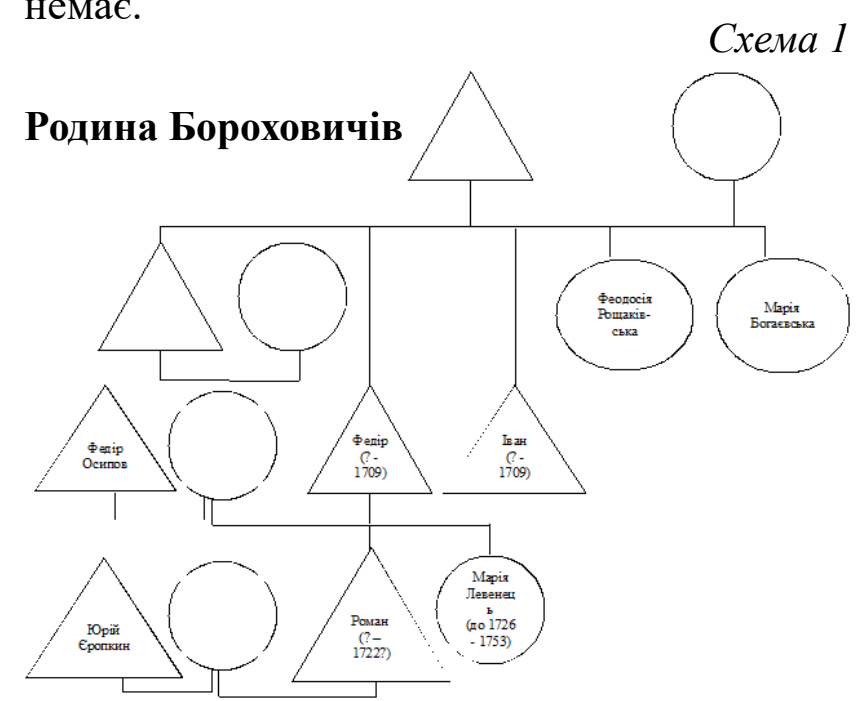


10 Модзалевский, В. Л. Малороссийский родословник, 84; Лазаревский, А. Борохович Михайло, 547.

11 Павленко, С. О. (Упоряд.). (2007). Доба гетьмана Івана Мазепи в документах. Київ: Видавничий дім «Києво-Мо-

гилянська академія», 448, 557; Бутич, Іван (Упоряд.). (2002). Універсали Івана Мазепи 1687-1709. Київ; Львів: НТШ, 63, 446.

12 Лазаревский, А. Борохович Михайло, 548; Бутич, Іван. Універсали Івана Мазепи.

13 Лазаревский, А. Борохович Михайло, 548-549.

14 Там само, 548-550; Баранець, П. Історія.

15 Синяк, Іван (Упоряд.). (2020). Архів ранньомодерної украӥнської держави (Т. 6. Документи Ніжинського полкового суду 1745-1758, с. 343). Київ.

16 Яковенко, Н. (2006). Нарис історії середньовічної та ранньомодерної
Коротку історію чотирьох поколінь цього роду вивчено лише фрагментарно. Батько Михайла - Андрій Борохович був гадяцьким обозним, як і пізніше (від 1672 р.) його син ${ }^{10}$. Ні роки життя батька, ні ім'я його матері невідоме. Прізвище та різні варіанти його написання - «Борухович», «Бурхович», «Борохивич» ${ }^{11}$ - можна пов'язати із іменем «Борух» - «благословенний», що вказує на його єврейське походження.

За життя Михайло Борохович нажив значних статків. У його володінні, крім містечка Лютеньки 3 присілками, були містечко Борки $з$ присілком Загрунівкою, село Будища 3 двома присілками, село Тарасівка, лісові масиви, сінокоси, орні землі, хутори, рибні ловлі, млини на Пслі, Будиській і Лютенській греблях, на Вищеборківській Романівській греблях на р. Грунь ${ }^{12}$.

Посада гадяцького обозного, а згодом полковника сприяла швидкому накопиченню грошових збережень. Із заповіту його дружини 1724 р. довідуємося, що «деньги были у насъ спрятаны въ погребі, въ дворі лютенскомъ. А было тъхь денегъ въ одномъ судениі пять тысячей и чотириста червоныхъ золотыхъ; другое суденце насыпано было талярами битыми, въ 57 якое вмъщается четыре гарнца меду; третье судение насыпано было копъйками сребрними старыми въ якомъ вмъщается меду семь или и больше гарнцовъ, того не упомню, только то знаю, что два человъка тое судно едва понести могли. Кромъ того два судениа насыпаны были разными деньгами: талярами, левами, полталярками, чвертками» ${ }^{13}$.

У Михайла та його дружини Олени Іванівни було багато дітей, з яких живими на момент смерті батька були: Максим, Федір, Іван, Феодосія і Марія (див. схему 1). Докладно історію цієї родини та складні взаємовідносини між синами, невістками та вдовою-полковницею, висвітлені у заповіті Олени Борохович, розглянуто у статті Петра Баранця ${ }^{14}$

Полковник загинув 13 жовтня 1704 р. під час військової кампанії Північної війни. У заповіті вдови помилково зазначено, що він загинув у Польському поході, який розпочався 1705 р. Що не дивно, адже Михайло Андрійович був учасником багатьох походів як на території Гетьманщини, так і за іiі межами. Зокрема, був учасником Азовсько-Дніпровських походів 1695-1696 рр., у результаті яких було розбито війська кримського хана та ханського гетьмана Петрика ${ }^{15}$. Він поклав голову під час кампанії 1701-1704 pр., коли козацькі полки під його орудою та Данила Апостола й Михайла Миклашевського воювали в Естляндії, Лівонії та Литві ${ }^{16}$. 
17 Бутич, Іван. Універсали Івана Мазепи, 501.

18 Кривошея В.В. Козацька старшина, 96.

19 Баранець, П. Історія, 59.

20 Павленко, С. О. Доба гетьмана Івана Мазепи.

21 Лазаревский, А. (1889). Отрывки из летописи Мгарского монастыря. Киевская старина, 8 (XXV), 42-49.

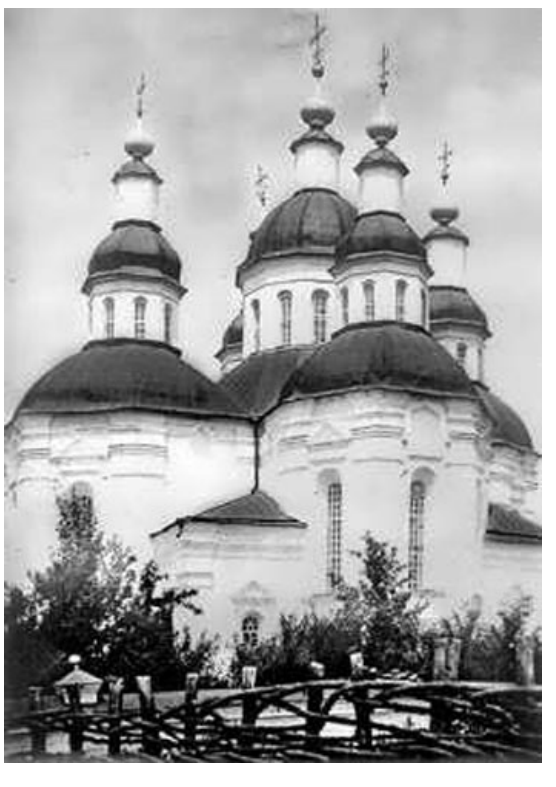

Puc. 6.

Успенська церква в

с. Лютенька

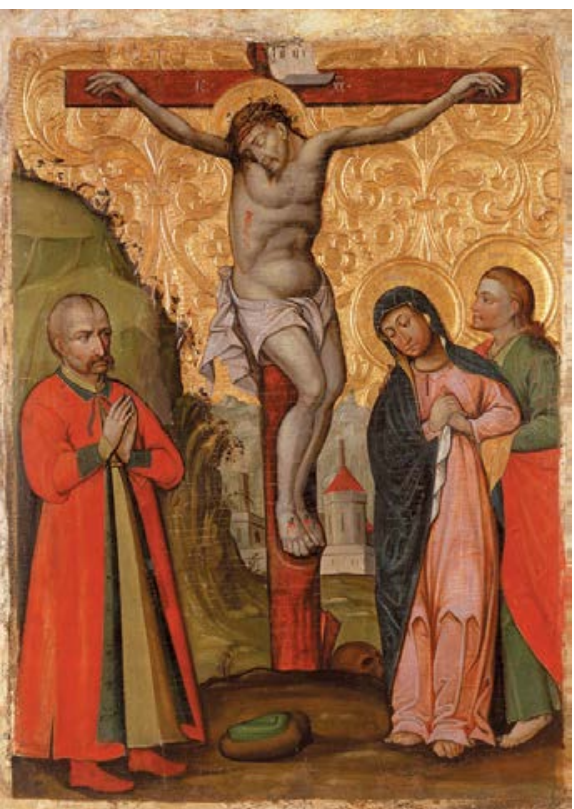

Рис. 5. Ікона Розп'яття із зображенням лубенського полковника

Леонтія

Свічки

Після його смерті гетьман Іван Мазепа узяв «nід оборону» вдову із нащадками, підтвердивши маєтності універсалами від 6 листопада 1704 р. та 7 січня 1707 р. ${ }^{17}$ Власність Олени Борохович швидко переділили ії сини та невістки. Вона бідкалася у заповіті, що Федір отримав у Мазепи універсал на маєтност матері - село Борки із Загрунівкою та Червону Луку, та викрав грошові заощадження; що онук Роман (наказний полковник Полтавського полку, квітень 1711 р. $\left.{ }^{18}\right)$, за протекцією тестя, виправив царську грамоту на села Тарасівку, Борки із Загрунівкою, а також на половину Лютеньки, які згодом перейшли до його вдови Тетяни Савичевої та ії наступно- го чоловіка Федора Єропкіна. Частина володінь без сіл відійшла як посаг і спадщина до родів Рощаковських, Бугаєвських і Левенців, за доньками Марією, Феодосією та онукою Марією Романівною. Ще частина Лютеньки, що належала полковниці, була відписана «на Ея Величество», як виморочна. Інша частина дісталася останньому її племіннику - Іванові Івановичу Косагову, який був лейтенантом Семенівського полку ${ }^{19}$

Активною була ктиторська діяльність родини. Окрім Успенської церкви, Михайло жертвував гроші на створення Михайлівської церкви Мгарського монастиря ${ }^{20}$, що був на території Лубенського полку. Його ім'я стоїть другим після лубенського полковника Леонтія Свічки (рис. 5) у реєстрі ктиторів. До речі, певний час між Бороховичем і Свічкою була жорстка конкуренція за «козацьку славу», i авторитет залежав не тільки від успіхів у військовій справі, а й від меценатської діяльності, яку проводила старшина, наслідуючи Івана Мазепу ${ }^{21}$. Полковниця також не шкодувала грошей на храмові потреби, зокрема, ще за життя полковника, Олена віддала у володіння Красногорівського монастиря, у якому полковник підтримував грошима будівництво Михайлівської церкви, поле, ліс і водяний млин на р. Хорол у с. Петрівці, ліс в урочищі Таранівщина, а у 1711 р. - ще три млинові ставки на Веприцькій греблі на 
22 Павленко, С. О. Доба гетьмана Івана Мазепи, 345.

23 Чайка, I. (2008). Шедевр українського бароко. День, 33 (22 лютого), 8.

24 Павленко, В. (2006). Свято-Успенська церква в с. Лютенька Гадяцького району. В Полтавський краєзнавчий

музей: Маловідомі сторінки історії, музеєзнавство, охорона пам'яток. Полтава: Дивосвіт.

25 Чайка, Л. Шедевр українського бароко, 8. p. Псел і ліс поблизу ${ }^{22}$. Однак, безумовно, основним об'єктом піклування родини була Успенська церква в Лютеньці (рис. 6, 7).

Історія Успенської церкви. Розміри храму за обмірами церковників початку XX ст. становили: довжина від східного головного вівтаря до західних дверей - 36,5 аршина $(25,958$ м), товщина стін - до 2 аршинів $\left(1,422\right.$ м) ${ }^{23}$. Була мурованою, дев'ятидільною, хрещатою, п’ятибанною. Гармонійна за структурою, церква вирізнялася оригінальністю архітектурного вирішення кожної грані, порталів, віконних обрамлень, карнизів тощо. Мала три престоли з приділами в ім'я архангела Михаїла і святої Трійці та різьблений п'ятиярусний іконостас, який було знищено у першій половині XX ст. ${ }^{24}$

Початковий вигляд церкви не зберігся. 10 червня 1748 р. всередині будівлі спалахнула пожежа, після якої іiі ремонтували та перебудовували. На початку XIX ст. із заходу споруджено чотириярусну дзвіницю. У 1887-1890 pp. iї розібрали, натомість збудували муровану двоярусну дзвіницю в архітектурних формах історизму ${ }^{25}$. Одночасно було перебудовано і сам храм.

1954 року церкву було взято під охорону держави як пам'ятку архітектури. 1955 року під керівництвом архітектора П. Захарченка було розроблено проект реставрації, що передбачав відновлення гіпотетичних

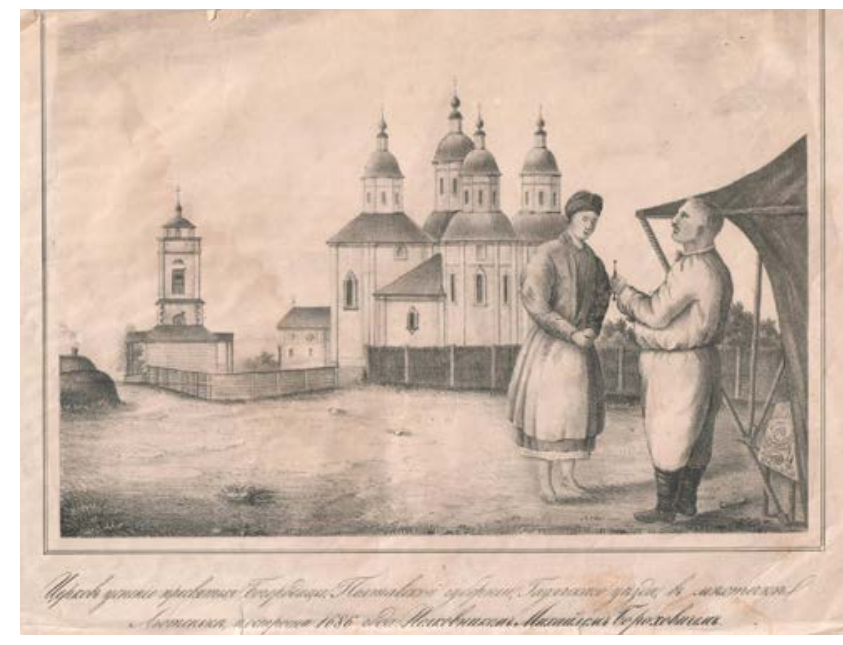

Puc. 7. Успенська церква в с. Лютенька. Малюнок козака Чепіги

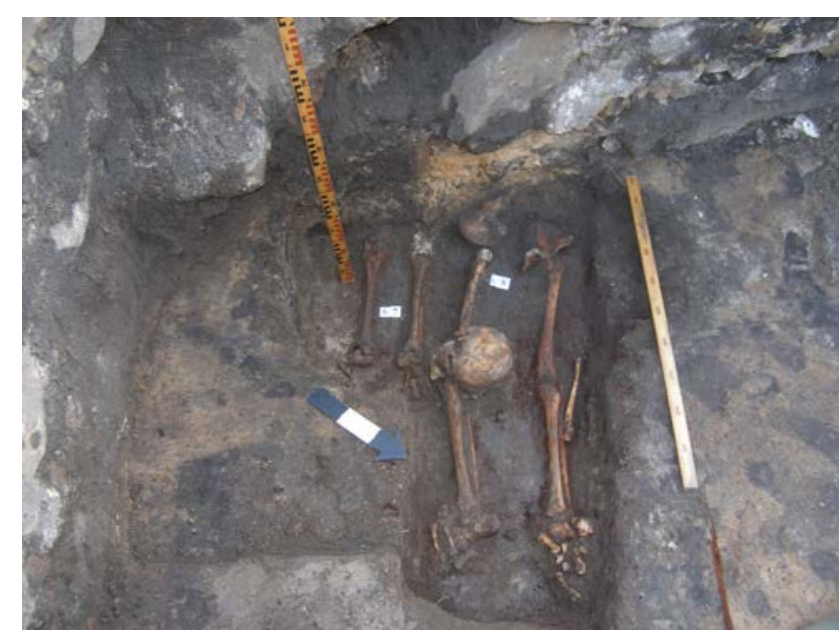

Puc. 8. Поховання XVII ст., частково зруйноване фундаментом Успенської церкви 


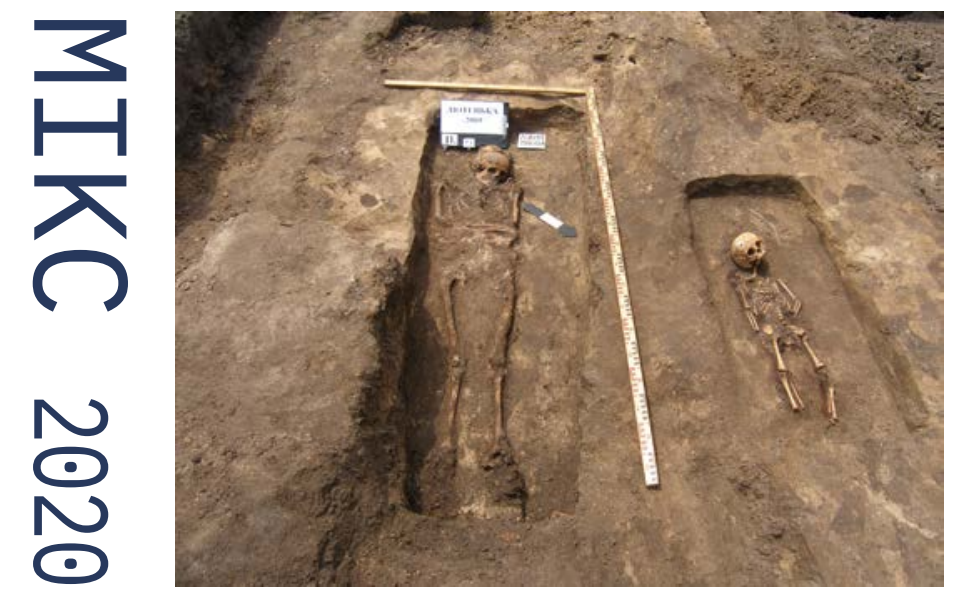

Pис. 9. Поховання дитини та дорослого з Успенського цвинтаря

26 Детальніше про так звану реставрацію див.: Кудрицький, А. В. (Ред.). (1992). Полтавщина: енциклопедичний довідник. Київ: Українська Енциклопедія, 500, 562; Чайка, Л. Шедевр українського бароко, 8; Павленко, В. Свято-Успенська церква, 104-107.

27 Кулаковський, П. Колонізаційна діяльність. початкових форм п'яти верхів, спотворених перебудовою 1890 р. Виконання реставраційних робіт було некваліфікованим, пам'ятка почала валитися. 1974 року церкву було підірвано. Остаточно ж рештки храму та дзвіницю знищили у квітні 1985 р., розібравши до фундаменту та розрівнявши ділянку технікою. Постановою Кабінету Міністрів України від 23 квітня 1999 р. Успенську церкву внесено до Програми відтворення визначних пам'яток історії та культури України ${ }^{26}$. Відтворення розпочала релігійна громада села Лютенька 2008 р., коли на місці колишньої церкви, через плановане нове будівництво, було ініційовано проведення згаданих археологічних досліджень. Однак муроване будівництво не розпочалося, оскільки забракло фінансування, а на ділянці побудували дерев'яну церкву, яка функціонує і досі.

Успенський ивинтар. Навколо Успенської церкви у 2009-2010 рр. було досліджено ділянку цвинтаря XVII-XVIII ст., який, як уже згадано, виник до початку будівництва мурованого храму (рис. $1,8,9$ ). Тому виявлені поховання датують як часом до спорудження храму, так і часом після його побудови. Більшість із цих поховань зроблено до будівництва мурованого храму, що свідчить про значну кількість населення нещодавно осадженої слободи. Точну чисельність осадників поки що не вдалося встановити, але вона мала бути значною, зважаючи на кількість археологічно зафіксованих поховань, які мали бути здійснені у проміжок близько 50 років, і дані щодо сусіднього Сарського городища, куди 1634 р. переселено 500 чоловіків із родинами ${ }^{27}$.

Усього зафіксовано 202 поховання (поховальні ями без збережених поховань не індексували, як і виявлені у перевідкладеному стані кістки, тому загалом поховань значно більше, до 300) (рис. 8-10). Рештки людей

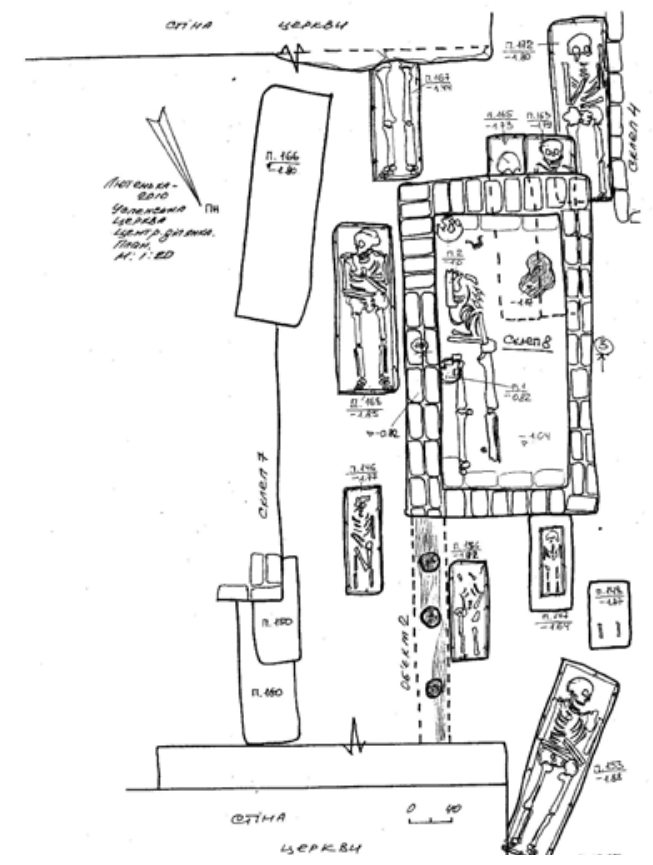

Puc. 10. Центральна ділянка розкопу, між фундаментами церкви, із залишками грунтових поховань XVII ст. склепу 8 XVIII ст. 


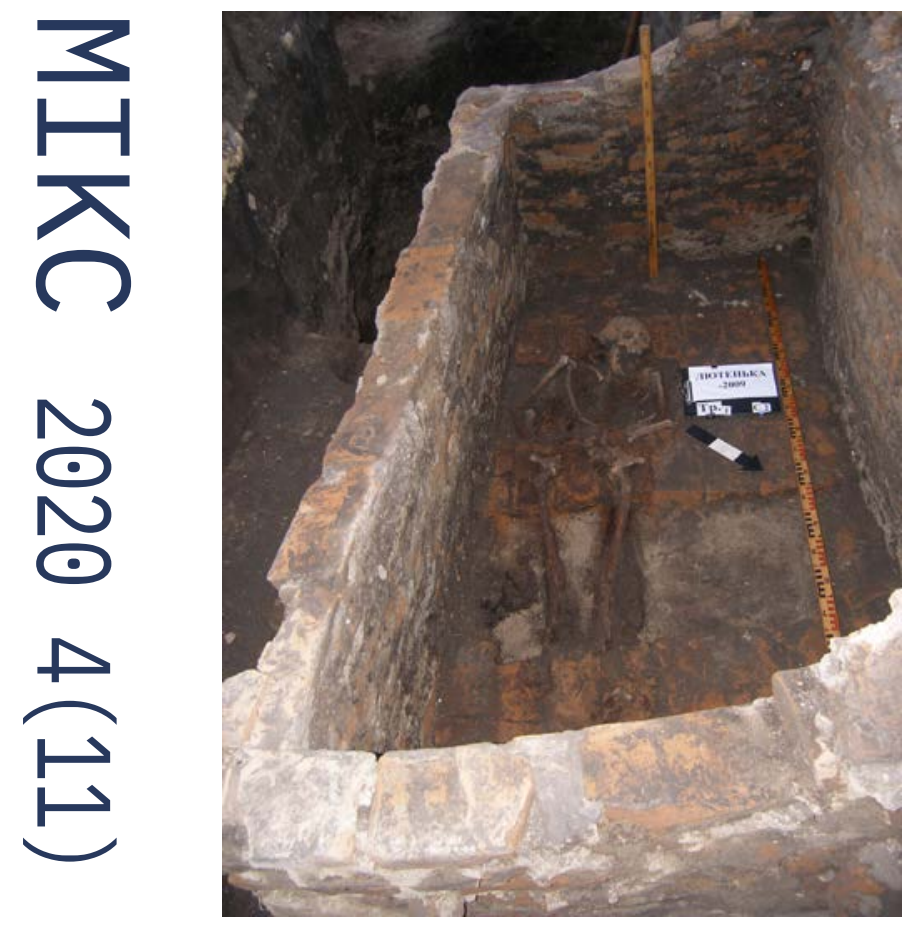

Рис. 11. Поховання у склепі 2

28 Мінейко, 0. В. (2014). Захворювання зубно-щелепного апарата у населення козацької доби (за матеріалами сотенного містечка Лютенька). Наукова збірка: Історична антропологія та біоархеологія України, 1, 131-143.

29 Долженко, Ю. (2017). Етнічний склад населення сотенного містечка Лютенька XVII ст. за даними краніології. Scriptorium nostrum, 3 (9), 101-120.

зө Коваленко, 0. В. (2001). Цвинтар XVII-XVIII ст. на Соборному майдані у Полтаві. Археологічний літопис Лівобе191 вивчали антропологічно. Попередній антропологічний огляд для звіту здійснили Л. Каськова та А. Артем'єв, захворювання зубо-щелепного апарату досліджувала О. Мінейко ${ }^{28}$, краніологічну характеристику надав Ю. Долженко ${ }^{29}$. Нині всі виявлені особи 3 грунтового могильника та склепів перепоховані біля стін Успенської церкви, із дотриманням православної обрядовості.

Планування некрополя $є$ близьким до рядового широтного. Всі могили орієнтовані в напрямку південь - південний захід, із різним кутом відхилення. Однак тривалість існування, обмеженість площі, бажання облаштувати місце останнього спочинку якнайближче до церковних стін зумовили формування його складної планіграфічної системи (рис. 10). 3 часом небіжчиків ховали на місці вже наявних могил, спочатку між могилами, потім і на місцях поховань, надгробки яких уже зруйнувалися. Поховання здійснено на різній глибині - від 1,11 м до 2,94 м від репера. Усього зафіксовано до п'яти вертикальних горизонтів розміщення поховань.

Частина поховань до 1687 р. виявилися «перерізаними», зруйнованими котлованом фундаменту церкви. Потрібно зауважити, що давні будівельники здебільшого не здійснювали перепоховання, а залишали кістки на місці, інколи лише перекладаючи порушені кістки. Також зафіксовано велику яму (із західної сторони храму, впритул до нього), в якій були хаотично розміщені (власне, скинуті) кістки людей (більше ніж 20 осіб). Така практика здійснення будівельних робіт і поводження 3 виявленими кістяками збереглася у Гетьманщині і у XVIII ст., зокрема простежувалася на Успенському цвинтарі в Полтаві ${ }^{30}$, що яскраво свідчить про ставлення до смерті у ранньомодерному соціумі.

У внутрішньому просторі церкви й поблизу стін здійснювали поховання, які вирізняються: стратиграфічно, використанням цегляних склепів, масивних дерев'яних домовин, вуглинами у заповненнях поховальних ям. Таких поховань XVIII ст. небагато, імовірно, це ктитори, старости та члени їхніх родин, священники. До XIX ст. або межі століть відносимо лише склеп 2 (рис. 11).

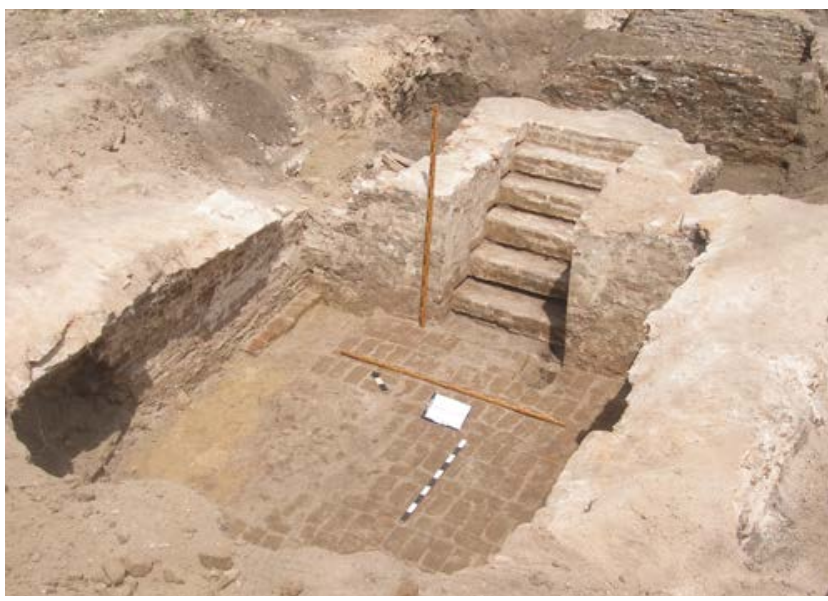

Puc. 12. Підземне приміщення в Успенській церкві 


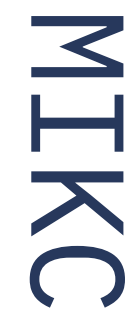

$\underset{0}{N}$

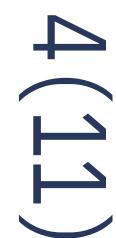

31 Нумерація склепів і поховань відповідає археологічним звітам. у статті їх розглянуто за хронологічним принципом.
У той час уже функціонував цвинтар навколо Всіхсвятської кладовищенської церкви, натомість територію навколо Успенської церкви було зайнято повністю, тому поховання тут не здійснювали. Отже, після побудови церкви загальнодоступний цвинтар припинив існувати, тут ховали лише ктиторів і священнослужителів.

Оскільки Михайло Борохович від початку планував розмістити в Успенській церкві усипальницю, в іiї центральній частині було побудовано підземне криптове приміщення, під підлогою якого облаштовано склепи самого полковника та членів його родини. У першій половині XVIII ст. у лівому приділі храму, «бабинці», упокоїлася його дружина Олена, а у правому - інші члени родини. Треба зауважити, що більшу частину склепів було пограбовано в часи боротьби з «опіумом для народу», причому неодноразово За монетою встановлюємо, що склепи грабували ще в другій половині 1930-х рр. Це ускладнює їх ідентифікацію.

Загалом досліджено 13 склепів: склепи $1,3,5,7,8,10-13^{31}$ і поховання 103, імовірно, належать членам роду Бороховичів, а решта - священникам та іншим неідентифікованим особам. Розглянемо їх докладніше.

Усю площу нефової частини займає підземне приміщення (рис. 12). Його індексовано як склеп № 10, проте невідомо, чи

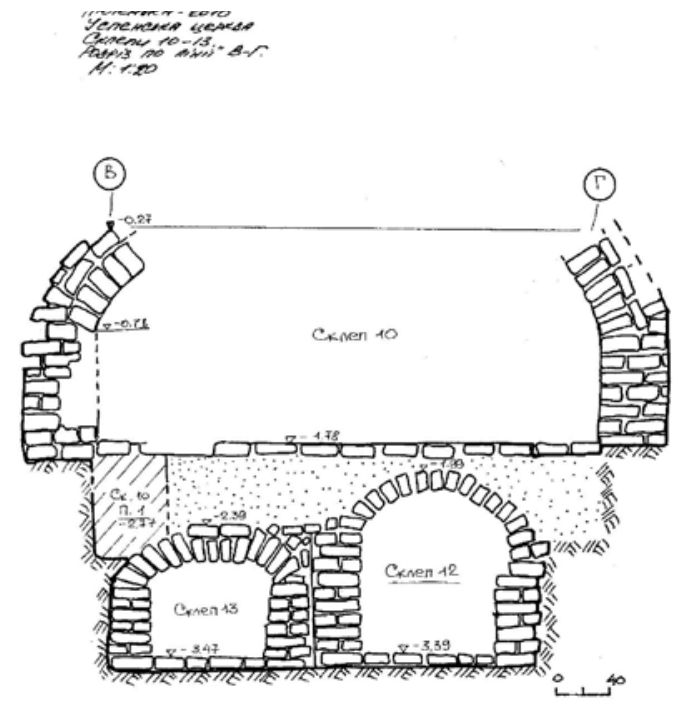

Puc. 13. Схема побудови склепів 10, 12, 13

здійснювали там поховання. Можливо, це була потаємна крипта, у якій стояли свічники й за потреби здійснювали відправи. Це єдиний склеп, досліджений в Успенській церкві, який має прикметні особливості: він має великі розміри, був запланований при будівництві та вписаний в архітектурне вирішення церкви - відповідає головній повздовжній вісі. Подібне вирішення має підземне приміщення із гробницею гетьмана Данила Апостола у Спасо-Преображенському храмі в Сорочинцях.

Підземне приміщення в Успенській церкві мало спеціально облаштований вхід. Із 


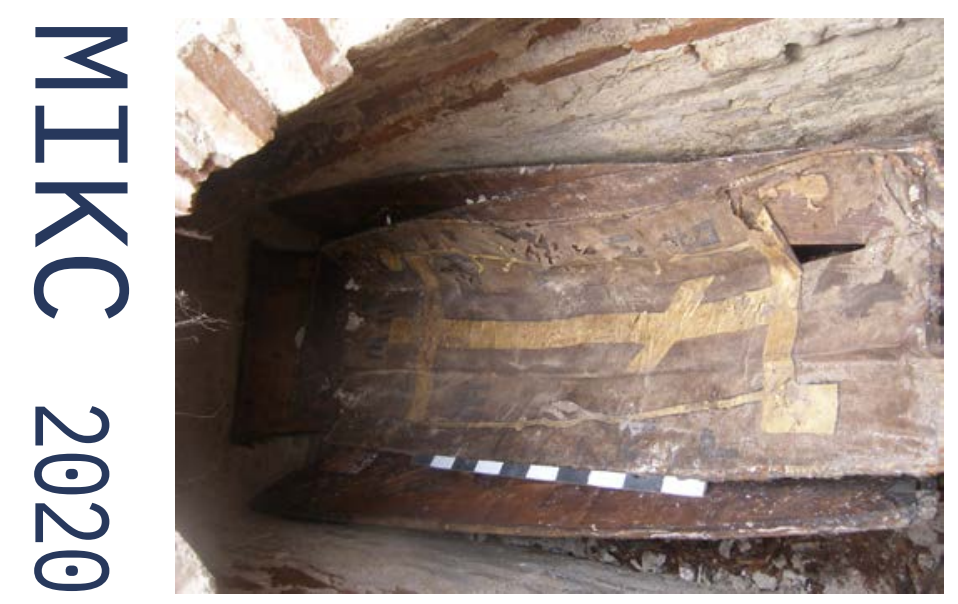

Puc. 14. Поховальний покров труни поховання зі склепу 12

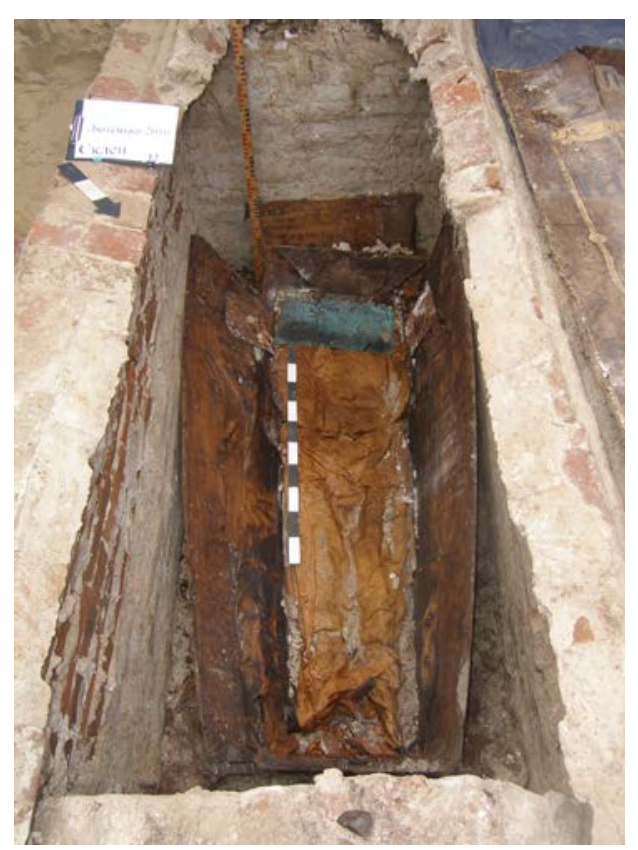

193

Puc. 15. Поховання Михайла Бороховича північно-східного боку, по центральній вісі храму, до нього ведуть шість східців. На кожну сходинку укладали дерев'яну дощечку. Внизу, за шостою сходинкою розміщувалися двері. Основне приміщення склепу має розміри 3,8 × 5,0 м. Стіни прямі, мають виразні ознаки заокруглення у формі арки.

Дно склепу рівне, цегляне. Цеглу викладено на пісковій підсипці у такий спосіб: одна цегла вздовж, одна впоперек: шість рядів - через одну, один ряд - дві повздовжні цеглини; десять рядів - чергування однієі поздовжньо, однієї поперечно розташованої; чотири ряди - поздовжньо розміщені цеглини; один ряд - поперечно. 3 правого боку від східців цегляну підлогу було розібрано на ширину 0,7-1,2 м. За свідченнями місцевих мешканців, до склепу після зруйнування храму був вільний доступ.

Під підлогою цього приміщення було влаштовано ще три склепи. Вони збереглися у майже непошкодженому вигляді, за незначним винятком.

Першим за часом облаштування є склеп 12, у якому, вочевидь, поховано Михайла Бороховича. У центральній частині підземної крипти (рис. 13), ближче до її південної стінки, розташували цегляний склеп, прямокутної форми, розміри якого $-3,04 \times 1,1 \times$ 1,45 м. Кладку виконано вздовж і впоперек почережно. Орієнтування склепу - на пів- нічний захід - південний схід. Дно склепу рівне, викладене $з$ поперечних рядів цегли, які чергуються 3 повздовжніми. Склеп вимуровано з цегли помаранчевого кольору, на вапняковому розчині. Верх склепу зберігся по всій довжині, він був зроблений шляхом укладання 12 рядів цегли, поставленої на ребро. Завдяки цьому поховання збереглося in situ й непошкоджене засипкою.

Імовірно, арку склепу будували так. У пази та на виступи стін були покладені дошки завширшки близько 0,25 м. Потім було викладено склепіння із цегли, а збоку (в ногах) залишено отвір, через який ті дошки витягли, адже залишилися не лише їхні сліди. Стіни були не побілені, а вимазані розчином, на якому зроблено кладку. Дерев'яна труна, поставлена на дно склепу, зверху оббита поховальним покровом (рис. 14). На ньому зображення, виконане сусальним золотом і чорною фарбою: центральне місце займає хрест із Голгофою. Вгорі напис «ІНЦІ» (Ісус Христос цар Іудейській). 3 правого боку на підніжжя уміщено тростину, із губкою (у вигляді кулі). 3 древка «виростають» 11 листків. Із іншого боку розміщений спис. Обабіч хреста літери, які потрібно читати так: «I $\mathrm{X} \Sigma »$ [під титлами], «НИКА», «К» (копіє), «Т» (тростина), «М Л» (милістю), «РБ» (раб Божий).

Рештки покійного вкрито саваном із жовтої шовкової тканини із рослинним орнамен- 

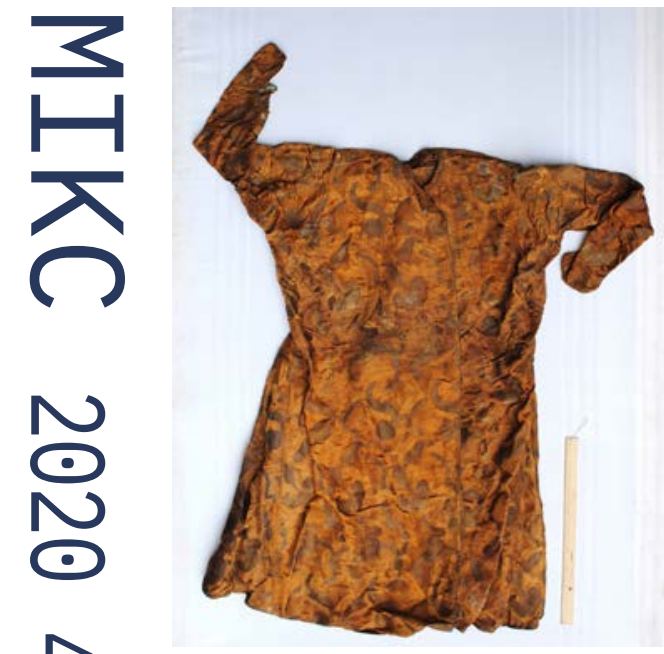

Puc. 16.

Жупан

Михайла

Бороховича

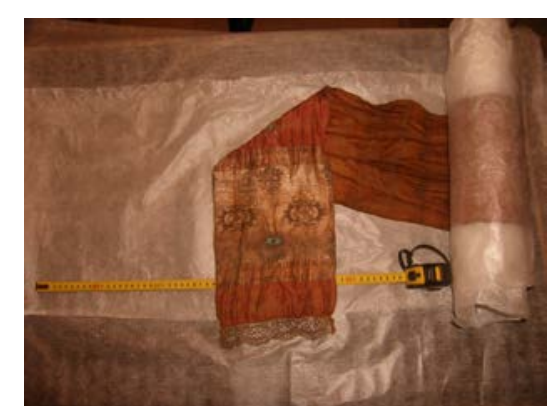

Рuc. 17. Пояс

Михайла

Бороховича

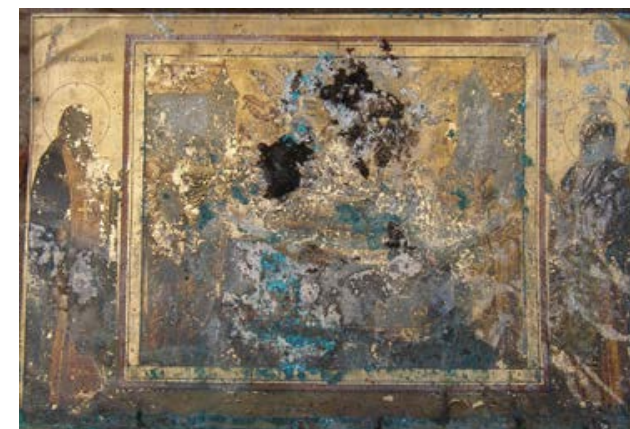

Рис. 18. Ікона Успіння Божої матері том. Руки складено на поясі. Верхній плечовий одяг пошито із парчевої жовтої тканини 3 рослинним орнаментом. Зверху (біля шиї) застібнутий на один гапличок. На рукавах аналогічні гудзики, по чотири на кожному. Гаплики шароподібної форми. Парчова тканина жупану кріпилася на червоно-малинову підкладку, яка майже не збереглася, як i сорочка. Рештки коміру сорочки містять рослинний орнамент - квітки. На ногах були штани, підперезані поясом. Пояс червоного кольору, тричі обернений навколо тулуба, кінці загорнуті вільно, в різні сторони. Пояс виготовлений із важкого шовку із тканим рослинним орнаментом. Полотно було розрізане, оскільки пояс має тільки одну кромку. Кінці поясу прикрашені мереживом, сплетеним із жовтої металевої нитки. 3 правого боку біля поясу зафіксовано скупчення сірих полотняних ниток i полотна із бронзових окислів (рис. 15-17).

Всередині труни, на торцевій стінці, у головах, було прибито ікону, яка пізніше завалилася на обличчя покійного. Розміри ікони - $50 \times 33$ см. Металева пластина із лицьового боку вкрита сусальним золотом. На пластині - ікона Успіння Божої Матері (рис. 18, 19). Зображення Успіння Богородиці виконано за традиційною візантійською схемою, витягнуте по горизонталі. Навколо гробу Богоматері розташовані постаті апостолів.

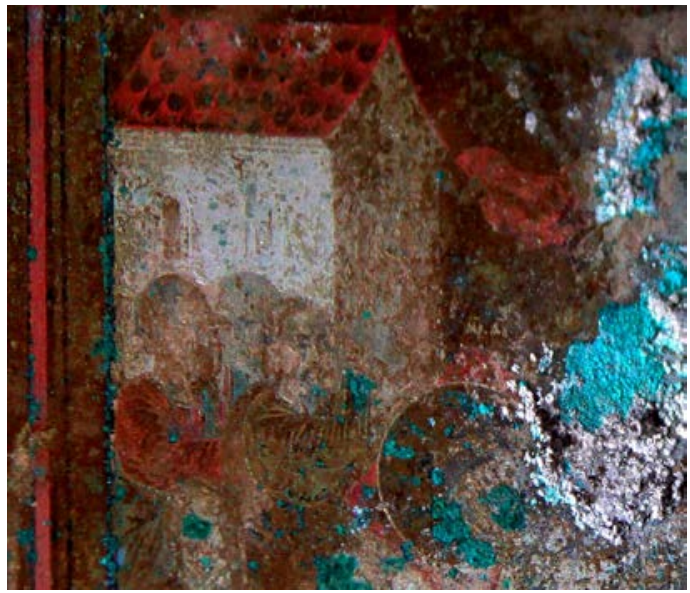

Puc. 19. Фрагмент ікони Успіння Божої матері зі склепу 12 із зображенням козаків 

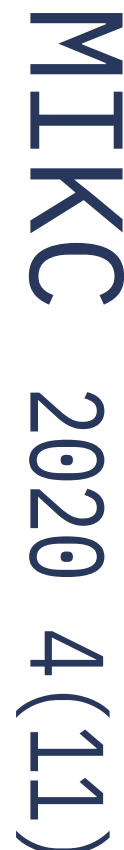

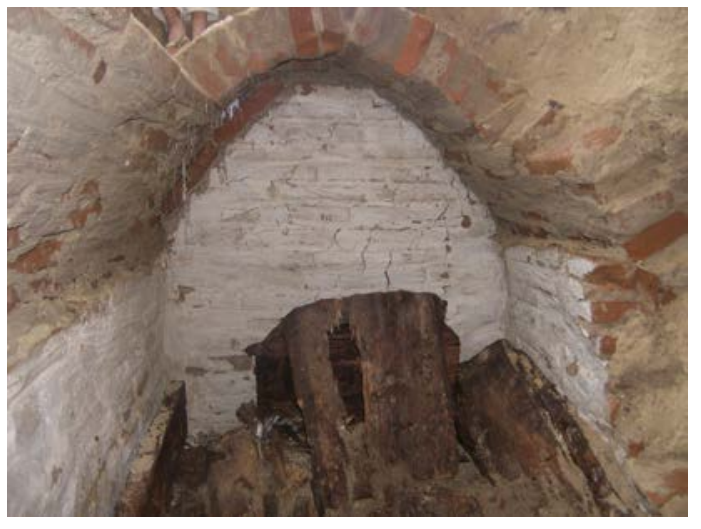

Рuc. 20. Склеп 11

32 Жолтовський, П. В. (1982). Малюнки Києво-лаврської іконописної майстерні Київ: Наукова думка (гр. 4 на с. 18 гр. 984 на с. 169).

33 Жолтовський, П. В. (1978). Украӥнський живопис XVII-XVIII cm. Київ: Наукова думка, 27
Серед них вирізняються п’ять постатей портретні зображення козаків. Можливо, замовлена полковником ікона містила портретні зображення членів його родини (його, трьох синів та онука). За межами рамки 3 іконографічним зображенням Успіння - постаті прп. Феодосія та Антонія Печерських. Можна припустити, що ікону виконали в Києво-лаврській іконописній майстерні, 3 роботами якої вона має багато спільних стилістичних ознак ${ }^{32}$. Ікона потребує реставрації та мистецтвознавчого опрацювання. Зважаючи на те, що майже не збереглося іконописних пам'яток із території Гетьманщини ${ }^{33}$, вона є однією 3 найраніших унікальних пам'яток українського іконописання.

Окрім цієї ікони, до труни було покладено ще дві. 3 правого боку, на боковій дошці, стояла ікона, написана на металевій залізній пластині. Ледь проглядає зображення, яке дає підстави припустити, що це лик Божої Матері Одигітрії. Зліва також пластина, з іконографічним зображенням Розп'яття. Залишилися лише кілька літер від напису на Розп’ятті - IНЦІ, решту втрачено.

Під головою покійного лежала подушка, виготовлена $з$ такої самої тканини, що й саван. Під нею - ще одна, під якою $з$ правого боку був пучок трави або квітів. Під спиною небіжчика розмістили третю подушечку.
Під підлогою підземної крипти, у північно-східному куті, впритул до стінок, виявлено верх склепіння склепу 11 (рис. 20) Конструкція склепу типова - прямокутна форма, розміри 2,70 × 1,6 м із товщиною стін в одну цеглину. Кладку виконано вздовж і впоперек почережно. Орієнтування склепу на північний захід - південний схід. Склеп

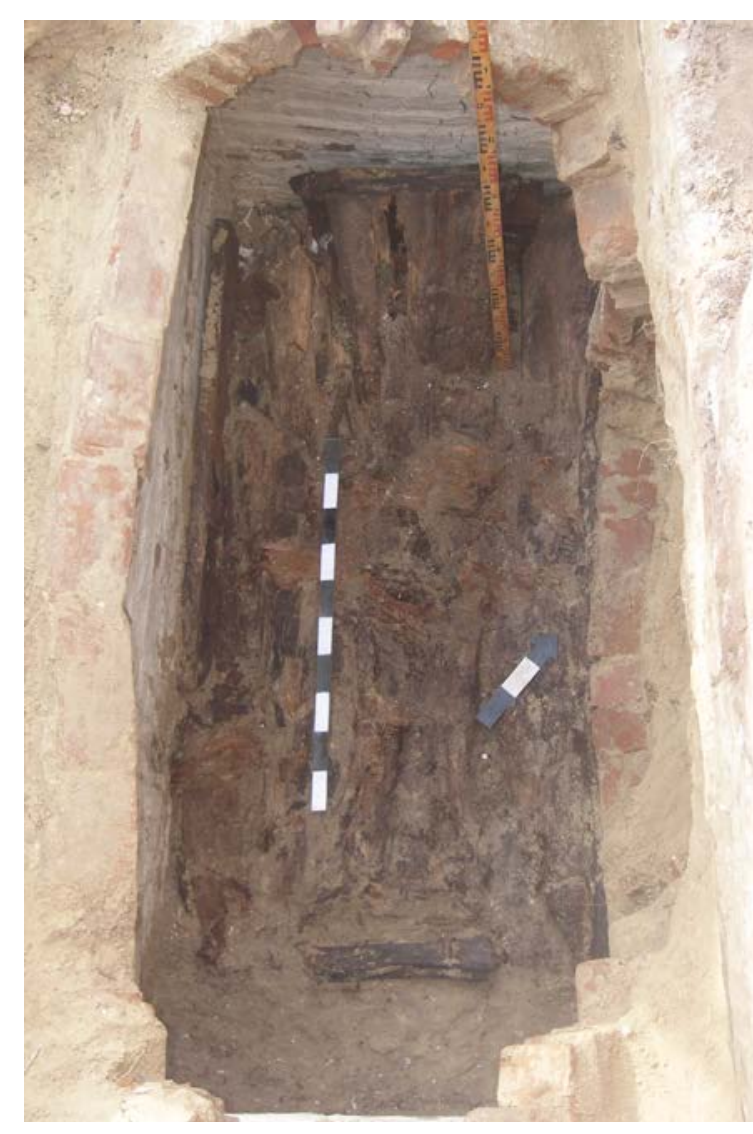

Puc. 21. Поховання у склепі 11 
Puc. 22. Пояс із поховання у склепі 11

Рuc. 23. Натільний хрест iз поховання у склепі 11 вимуровано з цегли помаранчевого кольору, на вапняковому розчині. Верх склепу зберігся по всій довжині, було укладено 11 рядів цегли, поставленої на ребро. Завдяки цьому поховання збереглося in situ й не пошкоджене засипкою. Висота стін, на які спирається склепіння, - 1 м, висота склепіння - 0,4 м. Дно склепу рівне, викладене з 17 поперечних рядів цегли.

Дерев'яна труна стоїть на двох рядах цегли. Зроблено з дубових великих дощок, ширина труни - 0,63 м, довжина - 1,95 м, висота $-0,47$ м; товщина дощок труни $-4,5$ см. Ззовні труна оббита шовковою тканиною, яка кріпилася прибитими на ткану стрічку бронзовими цвяшками $з$ фігурними шляпками, у вигляді квітки. Цвяшки прибито майже симетрично: $12,5,8,5,8,2,7,0,8,5$ см на одній стороні); 8,3, 7,0 см (на іншій стороні). Глибина здійснення поховання - 3,94 м.

На черепі покійного лежала металева (залізна) пластина, дуже пошкоджена корозією, розміри - $32 \times 22$ см. Спочатку вона була прикріплена до внутрішньої сторони торцевої дошки труни, а пізніше завалилася. Рештки фарби вказують на те, що на пластині була написана ікона, однак зображення повністю зникло. Під головою покійного подушка прямокутної форми, виготовлена 3 трави, завернутої у шовкову тканину.

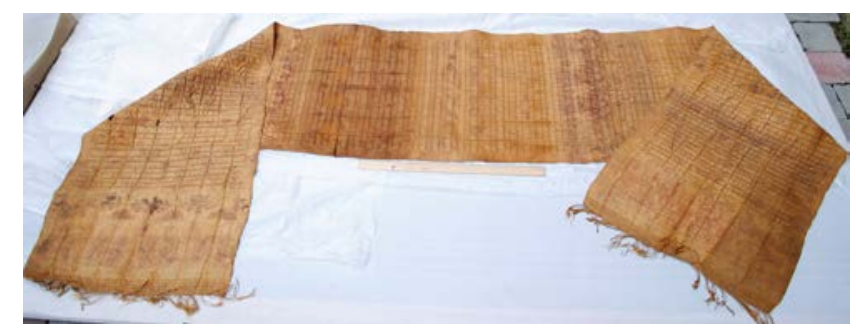

Поховання чоловіче (рис. 21). Зберігся одяг, а саме жупан, який доходив до колін, виготовлений із парчевої тканини з рослинним орнаментом, тканим жовтою металевою ниткою. Жупан завдовжки 1,1 м, мав два кармани. Запах і рукави застібалися на сім гудзиків (гапликів) округлої форми, з петелькою. На кістках ніг деінде проглядалися клапті тканини - рештки штанів. На ноги були вдягнені шматяні чоботи, форму яких неможливо реконструювати, без підков. Покійний був підперезаний жовтим шовковим поясом, складеним ушестеро, із рослинним тканим декором (рис. 22).
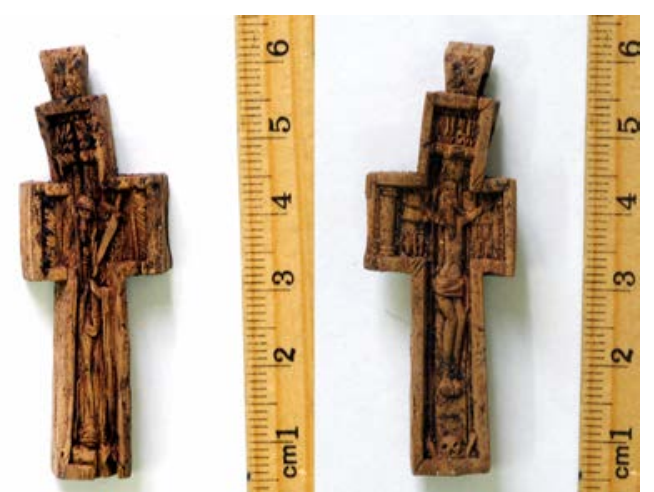


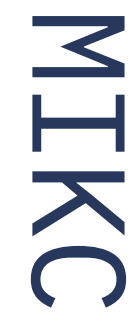

$\underset{0}{\infty}$

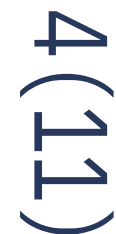

На руки покладено хустку з тонкого шовку, на якій збереглися плями червоного кольору. На хустці лежав дерев'яний різьблений чотирикінцевий хрест, 5,6 × 1,9 см. Обидва боки вкриті неглибоким різьбленням. Внутрішній простір обох сторін окреслено рамкою. Вушко зрізане, округле із насічками, у вигляді косого хреста. На лицьовому боці центральне зображення розп'ятого Христа на фоні єрусалимської стіни (рис. 23). Хрест, на якому розп'ятий Христос, не виділений, він покоїться на Голгофі, яка зображена у вигляді черепа та кісток Адама. На лівому рамені - колона. Вгорі, у прямокутній рамці,

34 Лазаревський, А. Борохович Михайло, 551. Цей пояс нині теж експонується у Полтавському краєзнавчому музеї імені В. Г. Кричевського.

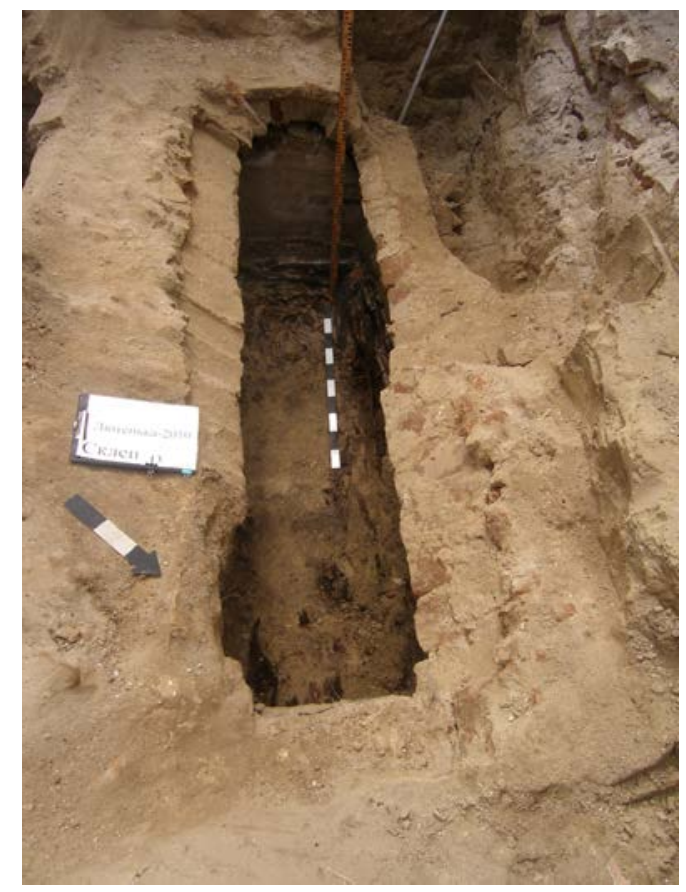

напис «ІНЦІ». На зворотному боці зображено Богоматір, яка тримає у лівій руці за лезо меч. Постать Богоматері видовжена, тонкими лініями зображено її одяг - довгий хітон. На краю рамен - виті колони. Вгорі, у прямокутній рамці, напис «МАРІЯ». Тло вкрите наколами. Іконографічний сюжет подібного типу трапляється рідко, він символізує момент, коли Богоматір простромлює перед Розп'яттям груди мечем. Аналогії є у православних сюжетах «Богородиця Меченосиця», «Богородиця семистрільна», «Умягчіння злих сердець».

Напевно, це поховання когось із синів полковника - Федора або Івана, які обидва померли 1709 р. Вважаємо, що одного було поховано у склепі 11, а іншого - у склепі 13.

Склеп 13 розташований поряд із склепом 12, у його центральній частині, ближче до північної стінки (рис. 24). Над склепом 13 цегляну підлогу по всій довжині склепу 10 розібрано. Враховуючи цей факт, а також пошкодження поховання у ділянці живота й тазу покійного, вважаємо, що саме на цей склеп натрапили церковники у середині XIX ст., гадаючи, що відкрили склеп полковника. Вони, як згадує Олександр Лазаревський, дістали звідти пояс, який використовували під час богослужінь ${ }^{34}$.

Стіни склепів 12 і 13 розташовані впритул. Конструкція останнього типова - пря- 

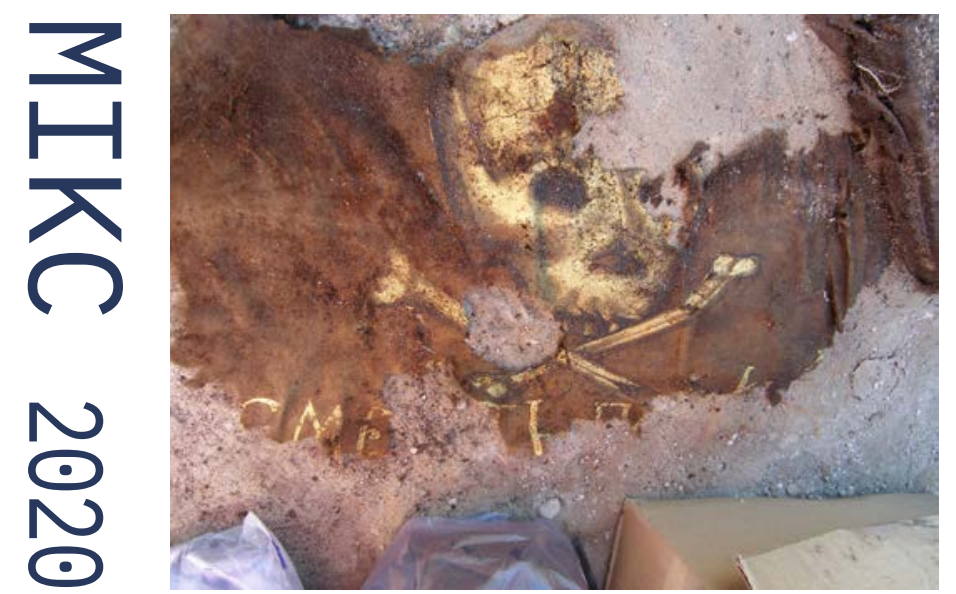

Puc. 25. Фрагмент поховального покрову iз поховання Олени Борохович

Puc. 26. Фрагмент поховального покрову із поховання Олени Борохович iз зображенням герба мокутна форма, розміри 2,65 × 1,4 м. Кладку виконано вздовж і впоперек почережно в одну цеглину. Орієнтування склепу - на північний захід - південний схід. Склеп вимуровано з цегли помаранчевого кольору, на вапняковому розчині. Верх склепу зберігся по всій довжині, він був зроблений шляхом укладання 12 рядів цегли, поставленої на ребро. Дно викладено з цегли через ряд.

Імовірно, склеп було пограбовано через провалля у ногах (у північно-східній частині). Збереглися лише залишки труни, оббитої шовковою тканиною із рослинним орнаментом (рис. 25). Оббивку здійснено за

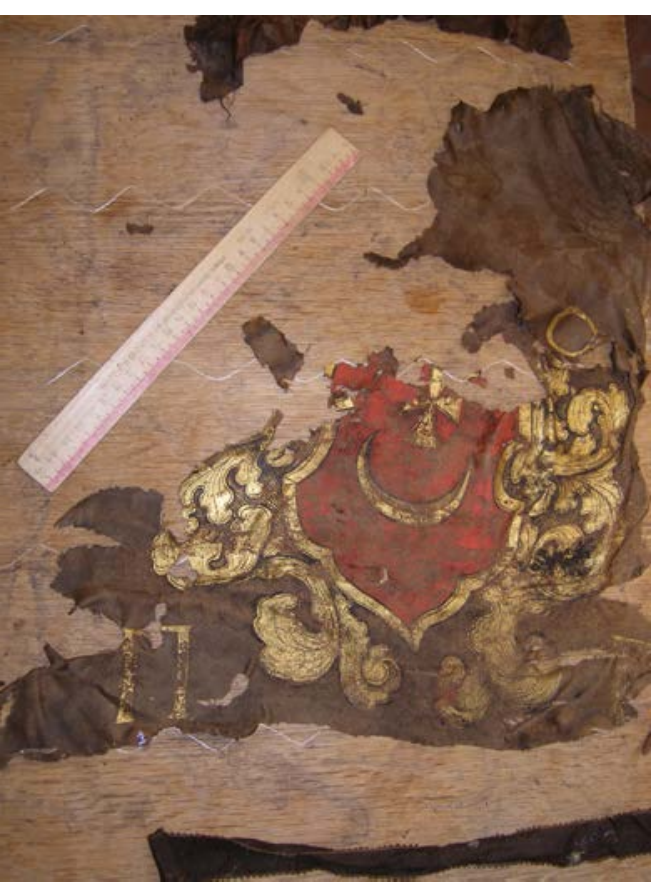

допомогою металевих цвяшків і вузької закріплювальної мережаної смужки. Труна, як і інші, мала декоративні залізні ручки. Заповнення склепу перемішане. Від одягу померлого залишились лише окремі фрагменти. В головах зафіксовано рештки подушки, набитої сухими васильками. Фрагменти залізних пластин, укритих корозією, вказують на те, що у труні була ікона, іконографію якої встановити неможливо.

Решта членів родини упокоїлася в інших частинах Успенського храму. Зокрема, Олена Іванівна була похована у склепі 3 , що розташований у лівому приділі, ближче до центру церкви. Він складений із цегли без тавра, в один ряд, на вапняному розчині. Прямокутної форми, розміри $-2,7 \times 2,0$ м. Орієнтований на південний захід. Стіни нерівні, зсунуті під впливом вибуху або з плином часу. Верх завалився до середини.

На дні виявлено поховання - у дубовій труні, яка зверху вкрита поховальним покровом, виготовленим із шовкової тканини 3 рослинним орнаментом, у вигляді квіток із пагонами та листям. На покриві збереглися фрагменти із розписами сусальним золотом: iз зображенням черепа та перехрещених кісток і написом «смерть [победит]» (рис. 25). Імовірно, на покрові було зображено розп'ятого Христа на Голгофі. 


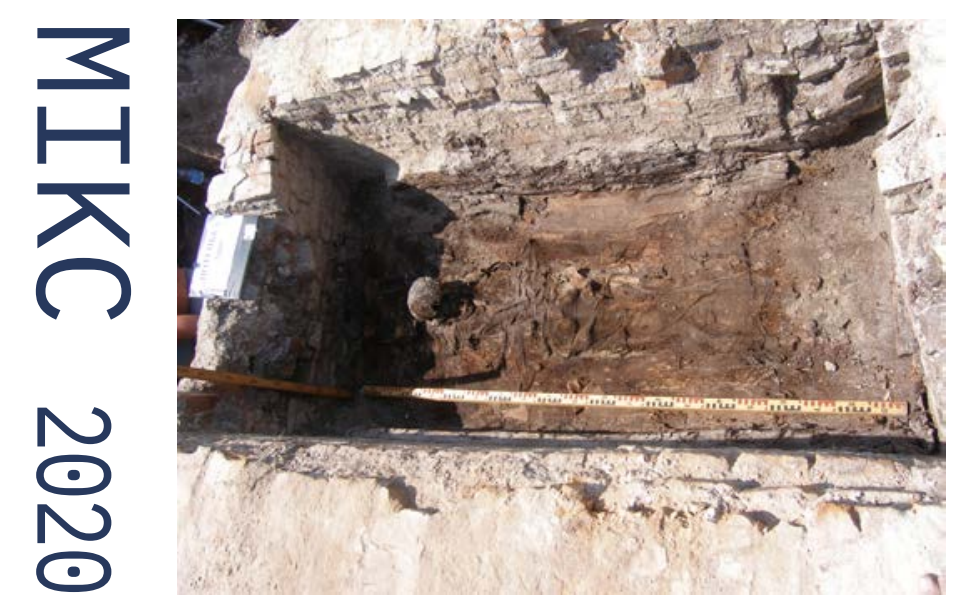

Рис. 27. Поховання Олени Борохович

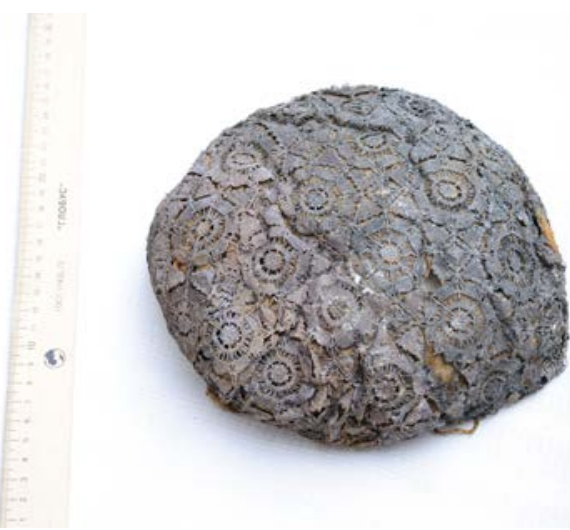

Puc. 28. Мережевний чепець Олени Борохович
На верхній частині поховального покрову намальовано герб Бороховичів, виконаний червоною, чорною фарбами та розписами сусальним золотом (рис. 26). Щит герба: на красному полі зображення золотого кавалерійського хреста, знизу - золотий півмісяць, роги якого спрямовані догори. Щит обрамлений золотими рослинними пагонами. По кутах герба літери (згори, зліва направо: [літери немає], «О», «П», «Г», тобто - [Борохович] Олена полковниця гадяцька). Верх герба, окрім правого кута, втрачено. Герб такий самий, як на портреті Михайла Бороховича.

Покров було прикріплено до труни невеликими металевими цвяхами з округлими шляпками. По лінії прикріплення нашито стрічку з металевою (срібною ?) ниткою, виконаною у техніці мережива. Домовина розмірами 2,2 × 1,2 м, мала дві залізні декоративні ручки. В головах померлої покладено ікону Пресвятої Богородиці, писану на дереві, розміром $30,0 \times 26,5 \mathrm{~cm}$. Виготовлена 3 цільної дошки. По краях, по периметру зроблено невисокий бортик: вздовж боків ширина бортика $-3,0$ см; згори і знизу $-4,0$ см. Рештки зображення дають змогу припустити, що це образ Володимирської Богоматері.

Небіжчицю покладено на спині, руки складені на поясі (рис. 27), на голові - чепець напівсферичної форми, виготовлений із металевої нитки (срібної ?) у техніці мережива, зшитий смужкою з грубої бавовняної нитки. Внутрішня основа виготовлена 3 тканини, зшитої також грубою бавовняною ниткою (рис. 28). Можливо, початковий колір головного убору був жовто-коричневий. Покійна була вбрана у верхній плечовий одяг (кафтан або чамару ?), пошитий із коричневого оксамиту. Одяг без застібок, по боках - розрізи. Внутрішня поверхня неблискуча, краї обшиті шовковою тканиною, початково зеленого кольору.

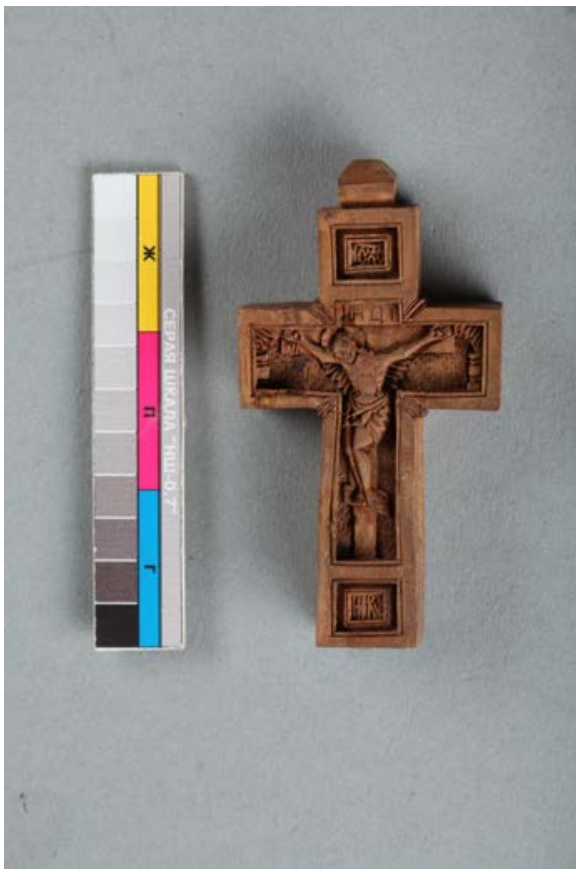

Puc. 29. Натільний хрест із поховання Олени Борохович 


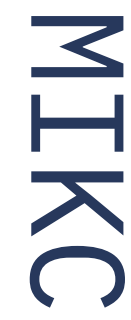

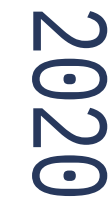

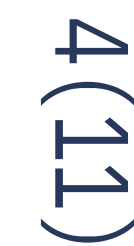

35 Коваленко, 0. (2003). Дерев'яні різьблені хрестики XVIII століття.
Під верхнім одягом - сукня, із шовку 3 рослинним орнаментом. Спідниця - зеленого кольору, керсетка - жовтого. Спідниця гофрована, пишна, має багато складок. Низ спідниці та керсетка декоровані смужкою мережива 3 рослинним орнаментом - трилисник із волютами. Керсетка без рукавів, на чотирьох застібках. Тканинний пояс зав'язаний вузлом спереду.

На сукню надітий фартух. Сукню виготовлено із коричневого шовку, з рослинним орнаментом. Попередницю зібрано у п'ять складок. Низ сукні декоровано зубчастим мереживом. Сорочка, напевно полотняна, не збереглася, від неї залишилися лише відбитки простого плетення на кістках.

У руки покійниці вкладений дерев'яний хрест (рис. 29). Він був на стрічці гайтані, зав'язаній вузлом і розрізаній. Стрічка імовірно шовкова, із геометричним орнаментом - повторюваними ромбами. Хрест дерев'яний різьблений, чотирикінцевий. Виконаний у техніці неглибокого рельєфу. На лицьовому боці розп'яття: внутрішній простір окреслений подвійною рамкою завширшки 0,4 м; по центру - зображення розп'ятого Христа. У внутрішній частині хреста, над розп'яттям, є літери «ІНЦІ». На всіх чотирьох раменах хреста, з обох боків, розміщено прямокутні медальйони, виділені подвійною рамкою, у яких є літери. Вгорі

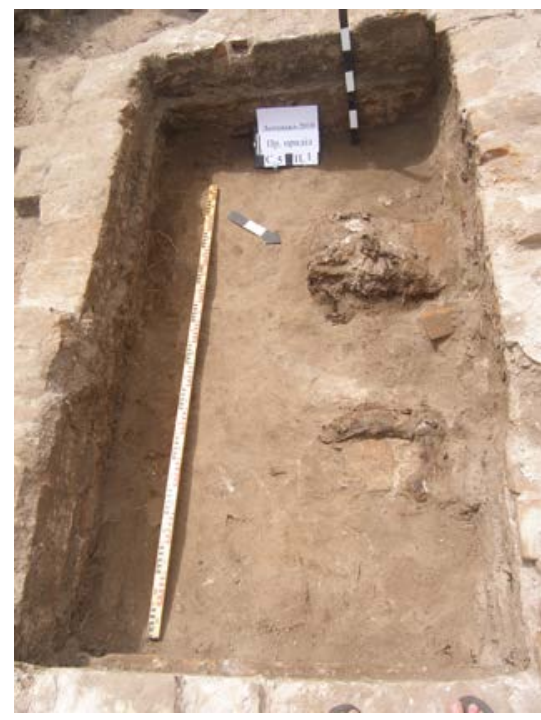

Рис. 30. Склеп 5. Поховання 1

на медальйоні напис «ICXC», унизу - слово «НИКА». На звороті центральною $є$ постать Богоматері $з$ немовлям Христом на руках. На голові Богородиці - корона, чітко вирізьблено контури та складки ii одягу. На правому плечі зображено зірку. 3 обох боків, на краю рамен внутрішнього хреста - арки, вгорі у медальйоні нерозбірливий напис, внизу ім'я «Марія». Позаду обох постатей вирізано сяйво. Тло середньохрестя з обох боків вкрито насічками. Вушко зрізане, пірамідальне, без прикрас. Розміри хреста - 7,8 × 4,4 cм. Подібний хрест виявлено у похованні жінки 1750-1780-х рр. 3 Успенського цвинтаря у Полтаві ${ }^{35}$. Біля тазу 3 лівого боку знайдено каблучку з жовтого металу без прикрас. 

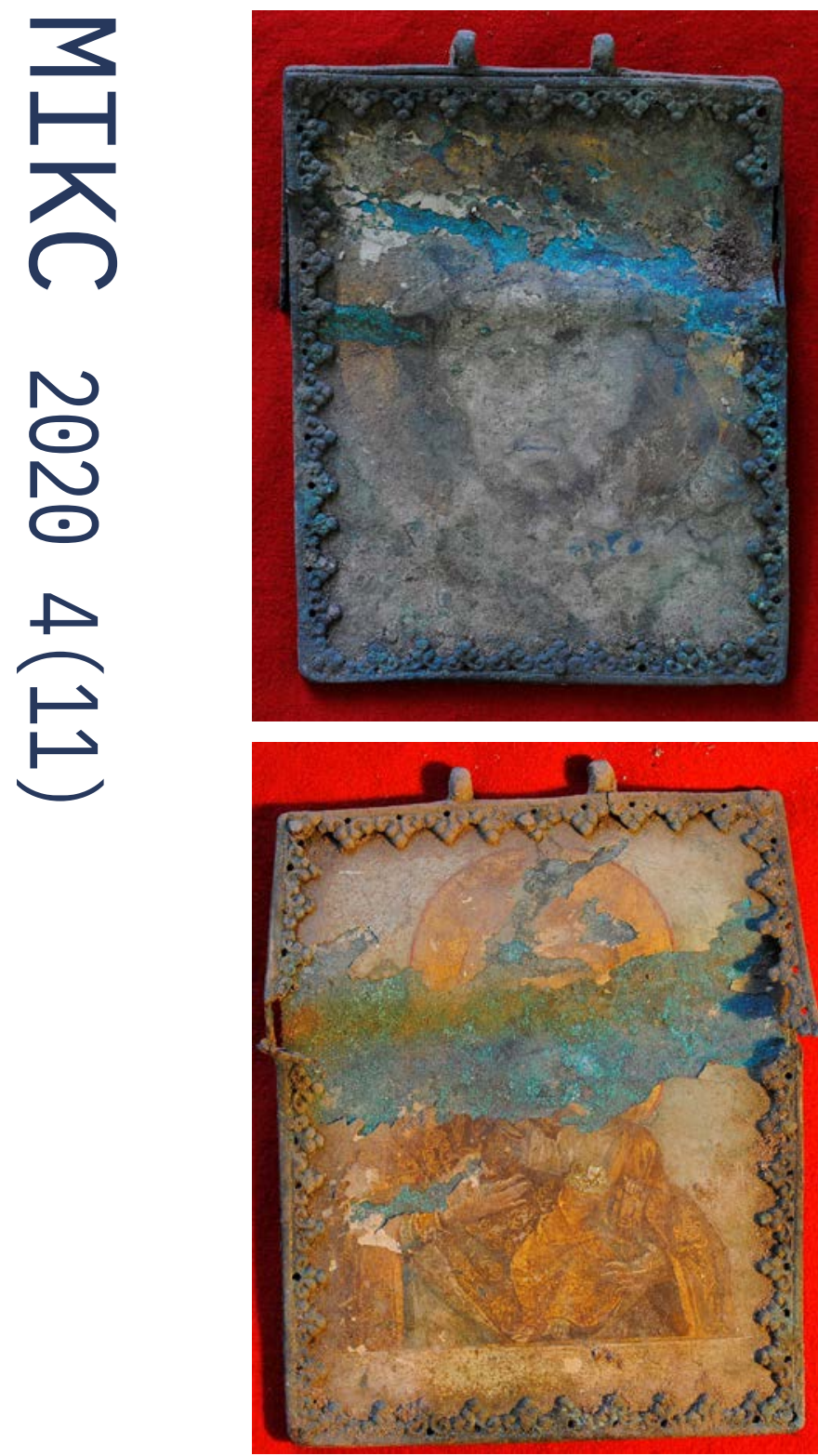

Puc. 31. Ікона зі склепу 5
Наступним за часом спорудження є склеп 5 , який розташований у правому приділі впритул до фундаментів церкви. Конструкція склепу типова: прямокутна форма, розміри $-2,90 \times 1,9$ м із товщиною стін в одну цеглину. Склеп вимуровано з цегли рожевого кольору, укладеної на вапняковому розчині Верх було зроблено шляхом укладання цегли, поставленої на ребро.

3 правої сторони склепу виявлено жіноче поховання (рис. 30). Оббита тонкою стрічкою мережива труна стояла на двох цегляних постаментах. Від поховання залишилося лише два масиви кісткового тліну і решток жіночого одягу, зокрема верхній плечовий одяг i, ймовірно, сукня жовтого кольору, виготовлена із шовку. Чепець сплетений із металевих (білих і жовтих) ниток, із квітковим орнаментом. На ногах залишки гофрованої спідниці жовтого кольору.

Упритул біля правої стінки склепу виявлено залізну ручку від труни. Труна була оббита тонкою стрічкою мережива 3 білої металевої нитки, що кріпилася бронзовими цвяшками. За головою покійниці знайдено архітектурно-декоративний виріб овальної форми, виготовлений із гіпсу, із зображенням ікони Успіння Богородиці.

Поряд, із лівого боку, на дні склепу знайдено чоловіче поховання. Домовина оббита смужкою мережива з білої металевої нитки.
Труна мала дві залізні дужкоподібні ручки Похованого покладено випростано, руки складені на поясі. Збереглися рештки одягу - сорочки 3 коміром, обрамленим плетеною ниткою. Вона застібалася на гаплики 3 жовтого металу (11 шт.). На поясі складений ушестеро пояс із рослинним орнаментом, колись був зеленого кольору.

За головою покладено ікону, писану кольоровим розписом на прямокутній металевій пластині. На лицьовому боці зображено сюжет «Богоматір Одигітрія», на зворотному боці - «Спас» (рис. 31)
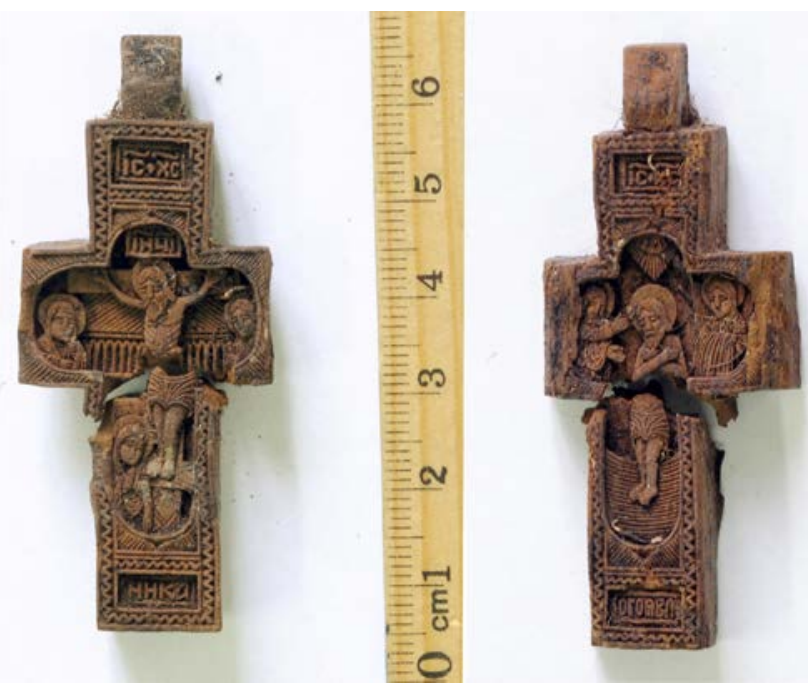

Puc. 32. Натільний хрест із чоловічого поховання у склепі 5 


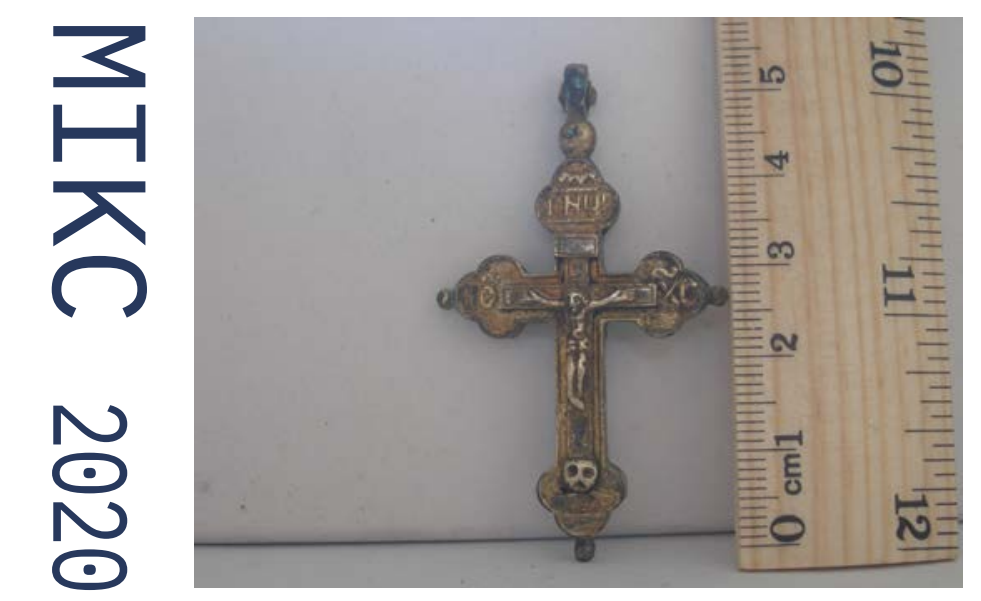

Puc. 33. Натільний хрест із поховання у склепі 6
На грудях покійного виявлено дерев'яний чотирикінцевий хрест (рис. 32). Обидва боки вкриті різьбленням. Вушко зрізане, пірамідальне, без прикрас. Лицьова частина містить сюжетне зображення розп'яття з пристоячими. Внутрішній простір окреслений рамкою шириною 2 мм, виконаною зигзагом. Центральний простір займає зображення розп'ятого Христа на фоні Єрусалимської стіни. У Ісуса немає традиційного для цього сюжету тернового вінця, очі заплющені. Над головою у прямокутній рамці, під титлами напис «ІНЦІ». Зліва погруддя Богородиці. Її ліва рука притулена до щоки, права - на грудях. Праворуч - погруддя Івана Богослова. Помітно лише його праву руку, яка притиснута до грудей. Біля ніг Христа, впритул, постать Марії Магдалини. Всі постаті виконані у три чверті в техніці неглибокого барельєфу. Обличчя об'ємно змодельовані, деталі конкретизовані. Вгорі у прямокутній рамці напис під титлами «IC XC». Внизу симетрично напис - «НИКА». Тло вкрито косими насічками. На зворотному боці зображено іконографічний сюжет Богоявлення (або Хрещення). Центральний простір займає зображення Христа. Він обернений у три чверті. Руки перехрещені на грудях. Ноги до колін занурені у води річки Йордан, яку стилізовано зображено паралельними плавними лініями. Над головою Христа стилізовано показано Бога-Отця як сонце, що визирає 3 небесного кола. Зліва - постать Іоанна Хрестителя, який нахилився до Христа і простяг до його обличчя праву руку. Праворуч - ангел, зображений у три чверті, який тримає у руках одяг Христа. Вгорі, у прямокутній рамці напис під титлами «IC XC». Внизу у прямокутній рамці підпис «БОГОЯВЛ».

Дно склепу цегляне. Цеглу викладено по діагоналі до довгої вісі склепу так, що утворилася «ялинка». Можливо, це були чоловік та жінка, наприклад син Михайла Бороховича Максим і його його дружина Тетяна. Дружина померла пізніше, після 1730 р. Східну стіну склепу, де, імовірно, вже був похований ії чоловік, розібрали (залишились сліди вторинної цегляної кладки), труну встановили на вимуруваний цегляний постамент.

Склеп 6 виявлено у правому приділі впритул до склепу 5. Форма прямокутна, глибина виявлення 0,4 м. Верху склепу немає. Внутрішнє заповнення мішане - будівельне сміття, дерево. На глибині 0,65 м знайдено поховання, яке являє собою складені купою кістки, череп, лопатки. Біля стін зафіксовано дерево від труни. Біля південно-західної стіни виявлено дві залізні дугоподібні ручки від труни. Домовина стояла на двох рядах цегли (глибина 0,77 м). У головах на домовині був ряд цвяшків із бронзовими шляпками, у вигляді рельєфних «квіток». Труна 


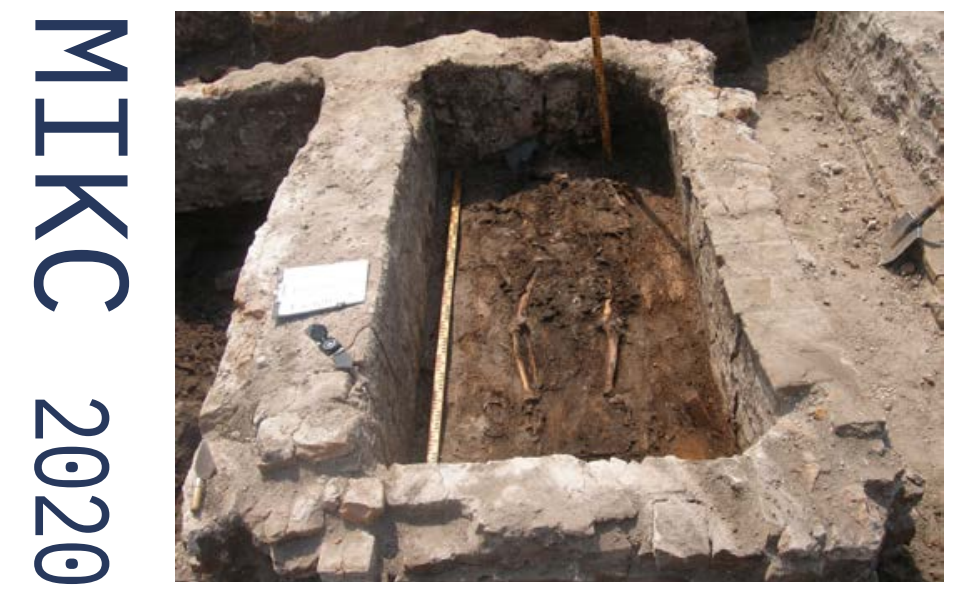

Рис. 34. Поховання у склепі 7

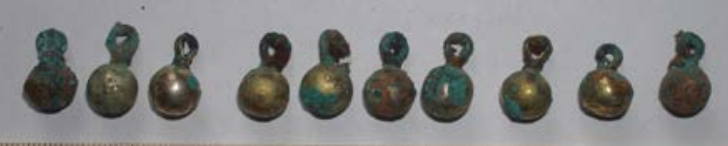

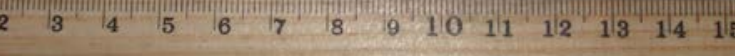

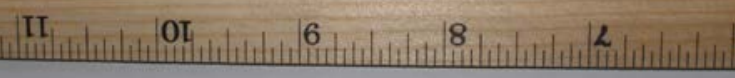

Pис. 35. Гудзики із верхнього одягу із поховання у склепі 7 оббита мереживом із простої нитки, обплетеної тонкою металевою жовтою ниткою. Кістки лежали купою у центрі домовини в хаотичному порядку. Біля них - натільний хрестик-мощевик із жовтого металу із зображенням страстей Христових (рис. 33). У переміщеному стані виявлено шматок тонкої фольги жовтого кольору з рельєфним рослинним орнаментом, який кріпився до дерева маленьким цвяшком. Імовірно, це оклад ікони. Зафіксовано також дрібні залишки тканини.

Дно склепу викладено $з$ цегли: почережно вздовж та впоперек. Два ряди (у головах i в ногах) - у дві цеглини. Глибина рядів 0,95 м, глибина дна - 1,08 м. Цегла розміром $0,3 \times 0,15$ м, прямокутної форми, рожевого кольору, подібна до стінної церковної. Кілька цеглин мають тавро у вигляді латинської літери «S». Можливо, у склепі був похований онук полковника - Роман.

Склеп 7 розміщений у правому приділі, впритул до склепу 6. Перекриття або склепіння немає. Заповнення змішане. Форма склепу прямокутна. Розміри 1,90 × 3,0 м. Ширина стін - 0,30 м. Дно склепу викладено $з$ цегли, цеглини покладені «ялинкою» (як у склепі 5) (рис. 34). Цегла без тавра. Під цеглою - шар посипки піском. У склепі виявлено поховання чоловіка: випростаний на спині, руки складені на поясі. Збереглися рештки одягу: по всьому кістяку траплялися шматки жовтої парчевої тканини. Верхній плечовий одяг застібався металевими кулястими гудзиками-гапличками, на зразок уже знайдених тут (рис. 35). На залишках черепа були залишки шапки або подушки із коричневого оксамиту, під ними - залишки сивого волосся.

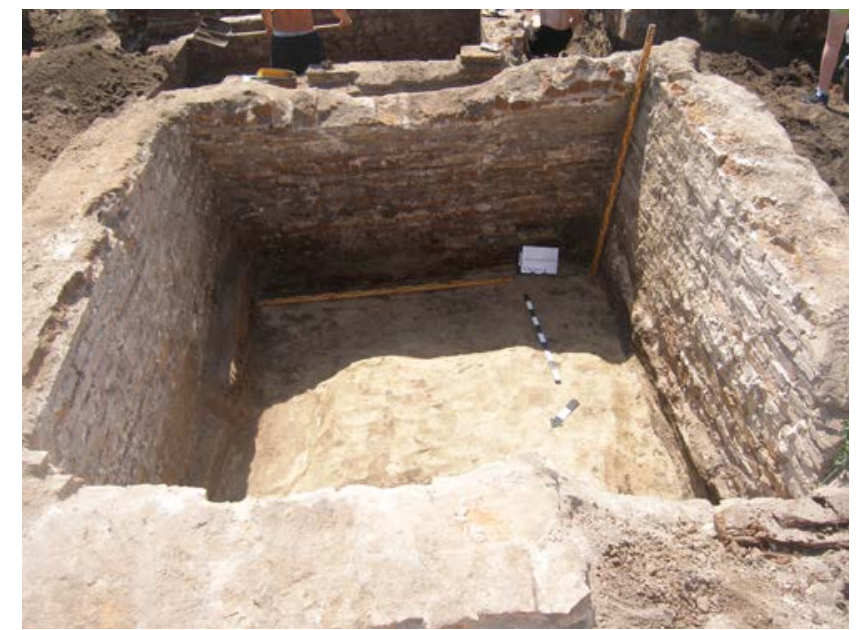

Рис. 36. Склеп 4

Труну оббито тканиною без закріплювальної смужки, збереглося мало цвяхів, що тримали оббивку. На бічних стінках труни прибито шість декоративних залізних округлих ручок, які кріпилися по одній на торцевих стінках і по дві - на бічних стінках. У головах покійного виявлено ікону, писану 
36 Відійшовши від теми, зазначу, що метричні книги с. Лютеньки за 1700-1919 рр. зберігаються у фонді 127:

Київська духовна консисторія (оп.

1014) ЦДІУАК, однак дослідники їх не вивчали з метою встановлення осіб священнослужителів, див.: Дмитренко, В. (2016). Матеріали черковного обліку населення Київської та Переяславсько-Бориспільської єпархій як джерело вивчення сойіумy

Гетьманщини XVIII століття. Полтава: Сімон. на металевій пластині, яка завалилася набік. Зображення на іконі збереглося погано, лише ледь помітні рештки лику Богородиці. На звороті, ймовірно, було зображення Розп’яття, від якого залишилися лише фрагменти латинських літер. Ікона має вушко для підвішування. Цей та інші склепи ідентифікувати достеменно неможливо.

Окрім описаних, досліджено ще склеп 1, який розташований у центрі Михайлівського приділу. Навколо домовини було викладено цеглу, без розчину (рис. 36). Похований чоловік 40-45 років. Розміри склепу $-2,7 \times$ $1,0 \times 0,8$ м; висота $-0,42$ м. Можливо, поховання здійснено після пожежі 1748 р. Ймовірно, тут спочив хтось із священнослужителів храму ${ }^{36}$.

Склеп 2 досліджено за межами церкви, із західного боку стіни, навпроти лівого приділу (рис. 11). Склеп прямокутної форми. Орієнтування південно-західне. Розміри $-2,8 \times$ 1,5 м. Викладений із цегли прямокутної форми на глиняному розчині. Дно не суцільно цегляне, а $з$ трьох рядів цегли, заглиблене до 1,58 м. Проміжки засипані піском. Труна початково була оббита тканиною, мала чотири залізні ручки. Поховання дорослої людини, 35-40 років. Можемо припустити, що це поховання Івана Івановича Косагова, генерал-лейтенанта Семенівського полку, племінника вдови Максима Михайловича
Бороховича, який був власником Лютеньки 1760 р. (кінець XVIII - початок XIX ст.).

Склеп 4 розміщувався по центру церкви впритул до склепу 3. Склепіння від початку було арковим. Стіни викладено звичайною почережною кладкою. Розміри $-2,90 \times 3,0$ м. У внутрішньому просторі виявлено, ймовірно, залишки дерев'яної долівки склепу. У мішаному заповненні склепу знайдено глиняну люльку та монету «денга» 1749 р. часів правління Слизавети Петрівни (1741 - 1762 рр.). Поховання пограбоване. Імовірно, тут похований хтось із священнослужителів.

Склеп 8 був влаштований по центру внутрішнього простору церкви, із незначним зміщенням праворуч від повздовжньої вісі храму. Розміри $-3,27 \times 1,92$ м. Перекриття немає, імовірно, було зруйновано внаслідок пограбування. Зверху у заповненні виявлено череп людини. Друге поховання - на дні склепу, ближче до східної стіни. Домовина також мала п'ять декоративних ручок. Кістяк пошкоджений. Цеглу на дні склепу викладено рядами. Імовірно, склеп споруджено у XVIII ст. для поховання літнього чоловіка. Пограбований не раніше 1931 p.

У нефі, праворуч від входу, були залишки ще одного склепу: купа битої цегли, великі шматки вапняного розчину та окремі кістки. 
Отже, Успенська церква та цвинтар є родинною усипальницею родини Бороховичів, священників і мешканців сотенного містечка Лютенька. Знайдені під час рятівних археологічних робіт матеріали $\epsilon$ унікальними зразками поховальних конструкцій, одягу, обрядовості тощо кінця XVII-XVIII ст., які значно розширюють наші уявлення та знання про різні аспекти здійснення поховань уявлення про смерть у часи Гетьманщини.

\section{References}

Baranets, P. (2013). Istoriia kozatsko-starshynskoho rodu Borokhovychiv. Kraieznavstvo, 3, 56-60 [in Ukrainian].

Bilousko, O.A., \& Mokliak, V. O. (2003). Istoriia Poltavshchyny (druha polovyna XVI - druha polovyna XVIII stolittia). Poltava [in Ukrainian].

Butych, Ivan (Ed.). (2002). Universaly Ivana Mazepy 1687-1709. Kyiv; Lviv: NTSh [in Ukrainian].

Chaika, I. (2008). Shedevr ukrainskoho baroko. Den, 33 (22 liutoho), 8 [in Ukrainian].

Dmytrenko, V. (2016). Materialy tserkovnoho obliku naselennia Kyivskoi ta Pereiaslavsko-Boryspilsko yeparkhii yak dzherelo vyvchennia sotsiumu Hetmanshchyny XVIII stolittia. Poltava: Simon [in Ukrainian].

Dolzhenko, Yu. (2017). Etnichnyi sklad naselennia sotennoho mistechka Liutenka KhVII st. za danymy kraniolohii. Scriptorium nostrum, 3 (9), 101-120 [in Ukrainian].

Hrushevskyi, M. (1908). Hospodarstvo polskoho mahnata na Zadnyproviu pered Khmelnychchynoiu. Zapysky ukrainskoho naukovoho tovarystva v Kyievi, 1 , 25-44 [in Russian].
Kovalenko, O. (2003). Dereviani rizbleni khrestyky XVIII stolittia. Poltavski yeparkhialni vidomosti, 9, 238239 [in Ukrainian].

Kovalenko, O. (2008). Zvit pro doslidzhennia na mistsi Uspenskoi tserkvy v s. Liutenka Hadiatskoho raionu Poltavskoi oblasti u 2008 rotsi. Poltava. Naukovyi arkhiv Instytutu arkheolohii Natsionalnoi akademii nauk Ukrainy (NA IA NANU), f. 1, 53 ark. [in Ukrainian].

Kovalenko, O. V. (2001). Tsvyntar XVII-XVIII st. na Sobornomu maidani u Poltavi. Arkheolohichnyi litopys Livoberezhnoi Ukrainy, 1, 145-150 [in Ukrainian].

Kovalenko, O., \& Luhovyi, R. (2009). Zvit pro doslidzhennia na mistsi Uspenskoi tserkvy v s. Liutenka Hadiatskoho raionu Poltavskoi oblasti u 2009 rotsi. NA IA NANU, f. 1, NA PKM, spr. 04-353, 152 ark. [in Ukrainian].

Kovalenko, O., \& Luhovyi, R. (2010). Zvit pro doslidzhennia na mistsi Uspenskoi tserkvy v s. Liutenka Hadiatskoho raionu Poltavskoi oblasti u 2010 rotsi. Poltava. NA IA NANU, f. 1, NA PKM, spr. 04-383, 223 ark. [in Ukrainian].

Kovalenko, O., \& Luhovyi, R. (2013). Materialy XVII st. z rozkopok tserkvy v s. Liutenka. Novi doslidzhennia pamiatok doby kozatstva v Ukraini, 22, 121-128 [in Ukrainian]

Kryvosheia, I. (2012). Uriadova ta neriadova starshyna Hadiatskoho polku v druhii polovyni XVII pershii tretyni XVIII st. Kyivska starovyna, 3, 22-32 [in Ukrainian].

Kryvosheia, I. I. (2015). Informatyvni mozhlyvosti reiestru pozyky do viiskovoho skarbu 1743 r. dlia vyvchennia istorii neuriadovoi starshyny Hetmanshchyny. Hileia, 101 (10), 10-14 [in Ukrainian].

Kryvosheia, V. V. (2010). Kozatska starshyna Hetmanshchyny: entsyklopediia. Kyiv [in Ukrainian]

Kudrytskyi, A. V. (Ed.). (1992). Poltavshchyna: entsyklopedychnyi dovidnyk. Kyiv: Ukrainska Entsyklopediia [in Ukrainian]. 
Kulakovskyi, P. (2008). Kolonizatsiina diialnist Konetspolskykh na Kyivskomu Zadniprovi. Zapys ky Naukovoho Tovarystva imeni T. H. Shevchenka, SSLVI: Pratsi istorychno-filosofskoi sektsii, 497-597 [in Ukrainian].

Lazarevskyi, A. (1889). Otryvky yz letopysy Mharskoho monastyria. Kyevskaia staryna, 8 (XXV) 42-49 [in Russian]

Lazarevskyi, A. (1890). Borokhovych Mykhailo, Hadiatskyi polkovnyk. 1687-1704 hh. Kyevskaia stary na, 9 (XXVIII), 547-551 [in Russian].

Luhovyi, R., \& Kovalenko, O. (2010). Doslidzhennia Uspenskoi tserkvy XVII stolittia v s. Liutenka. Nov doslidzhennia pamiatok doby kozatstva v Ukraini, 19 121-128 [in Ukrainian].

Mineiko, O. V. (2014). Zakhvoriuvannia zubno-shchelepnoho aparata u naselennia kozatskoi doby (za materialamy sotennoho mistechka Liutenka. Naukova zbirka: Istorychna antropolohiia ta bioarkheolohiia Ukrainy, 1, 131-143 [in Ukrainian].

Modzalevskyi, V. L. (1908). Malorossyiskyi rodoslovnyk (Vol. 2). Kyev: Typohrafyia t-va H. L. Frontskevycha y Ko [in Russian].

Pavlenko, B. (2006). Sviato-Uspenska tserkva $\mathrm{v}$ s. Liutenka Hadiatskoho raionu. In Poltavskyi kraieznavchyi muzei: Malovidomi storinky istorii, mu- zeieznavstvo, okhorona pamiatok. Poltava: Dyvosvit [in Ukrainian].

Pavlenko, S. O. (Ed.). (2007). Doba hetmana Ivana Mazepy v dokumentakh. Kyiv: Vydavnychyi dim "Kyievo-Mohylianska akademiia" [in Ukrainian].

Poshyvailo, B., \& Kovalenko, O. (2019). Tsehla iz fundamentu Uspenskoi tserkvy v seli Liutenka v Poltavshchyni. In Oles Poshyvailo (Ed.), Ukrainska keramolohiia (XIII (1), pp. 200-204) [in Ukrainian].

Sushynskyi, B. I. (2006). Mykhailo Borokhovych. Kozatski vozhdi Ukrainy. Istoriia Ukrainy v obrazakh yi vozhdiv ta polkovodtsiv KhV-KhIKh st. Istorychne ese u 2-kh tomakh (Vol. II, pp. 355-356). Odesa: YaVF [in Ukrainian]

Syniak, Ivan (Ed.). (2020). Arkhiv rannomodernoi ukrainskoi derzhavy (Vol. 6. Dokumenty Nizhynskoho polkovoho sudu 1745-1758, p. 440) [in Ukrainian].

Yakovenko, N. (2006). Narys istorii serednovichnoi ta rannomodernoi Ukrainy. Kyiv: Krytyka [in Ukrainian].

Zholtovskyi, P. V. (1978). Ukrainskyi zhyvopys XVII-XVIII st. Kyiv: Naukova dumka [in Ukrainian].

Zholtovskyi, P. V. (1982). Maliunky Kyievo-lavrskoi ikonopysnoi maisterni. Kyiv: Naukova dumka [in Ukrainian].

\section{Oksana Kovalenko}

\section{FAMILY BOROKHOVYCHY'S NECROPOLIS IN THE LYUTENKY (HADYACH REGIMENT)}

The article analyzes the materials of archaeological research of the cemetery of the XVIIXVIII centuries and the remains of the Holy Dormition Church in the village Lutenka (Poltava region). Lutenka was founded as a settlement in the '30s of the XVII century. Until 1646 it was owned by the 
Koniecpolski family. In 1648-1782, Lutenka functioned as a hundredth town as a part of the Hadiach, Poltava, and Zinkiv regiments. Its history is most closely connected with the Borokhovych family, in particular with Mykhailo Andriyovych, who during 1672-1687, with short breaks, was a Gadiatsky regimental convoy (oboznyi), and in 1687 - 1704 - a colonel. The article considers the family of Mykhailo and his second wife Olena Ivanivna, and the relationship between them and their children (Maxim, Fedir, Ivan, Theodosia and Mary), after the death of his father.

Most members of the family found their rest in the cemetery of the Church of the Assumption, specially built in 1687 as a family tomb. It was built in the centre of the Luten fortress on the site of an old wooden church, dated the first quarter of the 17th century. The newly built church was brick, nine-part, cruciform, five-bath. It lasted until 1985. In 2009-2010, the area of the soil cemetery of the XVII-XVIII centuries was explored around it, only about 300 burials. They are located in the latitudinal direction, with an attraction to the walls of the temple, often on the site of previously existing graves.

During the end of the XVII - first quarter of the XVIII century. The Borokhovychi buried family members in the underground space of the central part and on both sides of the church in crypt burials. 13 crypts are studied archaeologically, a unique state of preservation should be mentioned, which is the focus of this exploration. The burials of Mykhailo Borokhovych himself, his wife Olena and, probably, his sons were found and attributed. A detailed description of the constructions of the crypts, funeral attire, placement, accompanying ceremonial items: icons, crosses, etc. The materials of the end of the XVII-XVIII centuries expand our ideas and knowledge about various aspects of burial, the funeral rites of the Cossack officers and, in general, contribute to the clarification of ideas about death during the Hetmanate.

Keywords: Church of the Assumption, Lutenka, Gadyach, Mykhailo Borokhovych, Borokhovychi, cemetery, crypt, burial, icon, Assumption, cross. 